\title{
Environmental impact of fire
}

\author{
Drew Martin ${ }^{1 *}$, Mai Tomida ${ }^{2}$ and Brian Meacham²
}

\begin{abstract}
Fires are adverse events with tangible costs for property and human life. Quantification of the immediate and direct costs of fire provide a metric for understanding the social and economic impact of fire and for assessing progress in fire prevention and protection. In addition to their physical costs, fires have a range of less immediate and obvious adverse consequences on the natural environment. These include air contamination from the fire plume (whose deposition is likely to subsequently include land and water contamination), contamination from water runoff containing toxic products, and other environmental discharges or releases from burned materials. Current efforts to improve the sustainability of buildings focus on increasing energy efficiency and reducing the embodied carbon. This overlooks the fact that a fire event could reduce the overall sustainability of a building through the release of pollutants and the subsequent re-build. Several pieces of work exist on the quantification of the environmental impact of fire, but there is a need to pull this information together and to identify the technical gaps that still exist.

This publication pulls together the project aims, discusses the sources reviewed, presents a framework that was postulated for quantifying the environmental impact of fire, describes the gaps in knowledge, and presents a plan forward. The research resulted in a more in-depth appreciation of the environmental impact of fire, data, tools and methods that might be undertaken to analysis the environmental impacts as part of a fire engineering analysis, and highlights areas where future research is needed.
\end{abstract}

Keywords: Environment, Environmental impact, Impact of fire on environment, Impact of wildfire on environment, Fire risk analysis, Cost-benefit analysis, Life cycle analysis

Abbreviations: BCA, Benefit-cost analysis; BEES, Building for environmental and economic sustainability; BRE, Building research establishment; CA, Consequence analysis; CBECS, Commercial building energy consumption survey; DOE, Department of energy; EIA, Environmental impact assessment; EIF, Environmental impact of fire; EIS, Environmental impact statement; EN, European standard; EPA, Environmental protection agency; ETA, Event tree analysis; EU, European union; FM Global, Factory mutual global; FMECA, Failure mode, effects, and criticality analysis; FPRF, Fire protection research foundation; FTA, Fault tree analysis; GHG, Greenhouse gas; GIS, Geographic Information System; GOFA, Goal Oriented Failure Analysis; HAZAN, Hazard Analysis; HAZID, Hazard Identification; HX, Halogenated acids; ICC, International Code Council; IGCC, International Green Construction Guide;

ISO, International Organization for Standardization; LCA, Life-cycle assessment; NAHB, National Association of Home Builders; NASA, North Atlantic Space Association; NEMA, National Environmental Policy Act; NEPA, National Environmental Policy Act; NFPA, National Fire Protection Association; NIFC, National Interagency Fire Center; NIST, National Institute of Science and Technology; NOX, Nitrogen oxides; PAH, Polycyclic aromatic hydrocarbons; PBDD, Polybrominated dibenzodioxins; PBDF, Polybrominated dibenzofurans; PCB, Polychlorinated biphenyls; PCDD, Polybrominated dibenzodioxin; PCDF, Polychlorinated, dibenzofurans; PFC, Perfluorinated compounds; PM10, $10 \mu \mathrm{m}$ particulate matter; PRA, Probabilistic risk analysis; QRA, Quantified risk assessment; SLCA, Streamlined lifecycle assessment; SOX, Sulphur oxides; SP, Statens provningsanstalt; UN, United Nations; USDA, United States Department of Agriculture; USFS, United States Forest Service; VOC, Volatile organic compounds; WUI, WildlandUrban interface

\footnotetext{
* Correspondence: drew.martin@arup.com

${ }^{1}$ Arup, San Francisco, CA, USA

Full list of author information is available at the end of the article
} 


\section{Introduction}

Fires are adverse events with tangible costs to property and human life. Quantification of these costs provide a metric for understanding the social and economic impact of fire, which can be useful for assessing and influencing fire prevention and protection. In addition, fires also inflict adverse consequences on the natural environment. These include contamination of the air via the fire plume and its subsequent diffusion, with deposition of particulate and other materials likely to contaminate soil and water, contamination of soil and water from fire suppression runoff, which might contain toxic or hazardous materials, and direct exposure to soil and water from hazardous materials whose containers / containment systems may fail due to fire. While a great deal of research has been published on the quantification of the environmental impact of fire, the information has not previously been consolidated in a manner that facilitates identification of the research focus The impacts of concern and the gaps remain.

To address this concern, a survey of the literature was conducted on the environmental impacts of fire, how they might vary by fire source (e.g., building fire, wildland fire), and the various assessment approaches utilized. As part of the effort, a definition of environmental impact assessment was selected to bound the effort, a taxonomy to describe the broad range of environmental impact from fires was developed, a list of toxic products resulting from a fire was compiled, exposure pathways for toxic products associated with the fire and fire suppression were identified, and discussion regarding the quantification of environmental costs of fire is provided.

Internationally there are numerous definitions for environmental impact assessment (EIA). The definition provided in the Environmental Engineers Handbook (CRC, 1999), derived from the National Environmental Policy Act (NEPA) of 1969, was selected: the systematic identification and evaluation of the potential impacts (effects) of proposed projects, plans, programs, or legislative actions, relative to the physical-chemical, biological, cultural, and socioeconomic components of the environment.

Using this as a base, a working definition for the environmental impact of fire can be defined as: the systematic identification and evaluation of the potential stressors (hazards), of proposed projects, existing, built and natural, systems and their contents, resulting from an adverse, unwanted fire event, in terms of the physical- chemical, biological, cultural, and socioeconomic components of the environment.

Likewise, there have been various EIA approaches developed worldwide. The Environmental Engineers Handbook (CRC, 1999) presents a wide range of approaches and useful information for conducting an EIA at various levels of detail, including what issues to consider, how to quantify the effects, and resources to further the depth of the study. For this particular effort, the 'expert systems' level of analysis concept has been applied. In brief, this involved the use of expert judgment on the review of materials produced by others to assess the magnitude of the fire problem, production of environmentally unfriendly products of combustion, impact of those products on the environment, and so forth, without actually undertaking actual assessments of environmental impact. This was deemed appropriate for a literature review. Figure 1 shows the action items that are defined as part of the expert systems approach. Taking advantage of this organizational structure of the actions, the report has been modeled in this sequence.

In conducting the literature review, keyword searches were used to identify reports, studies and articles of interest. The outcomes of this effort were compiled into a database of resources. The resources were scanned to identify those with highest degree of relevance, for which more detailed reviews were undertaken. The reviews involved assessment of the event or study, critical findings, and gaps in understanding of the issues and associated data, tools and methods.

The initial search resulted in the identification of more than 150 resources consisting of published papers, research reports, standards and books. It included fires that resulted in documented adverse environmental impacts, the types of environmental impacts that have been identified and the associated exposure pathways, and the tools and methods used to assess impacts and associated costs. From these sources, a smaller selection of documents was chosen for more detailed review. These were selected by filtering around a refined set of parameters pertinent to the study. The types of documents selected are as follows.

Studies on building fires that have caused environmental damage, such as the Sandoz fire and chemical spill in Basel, Switzerland, and the Sherwin William's Paint Warehouse fire in Dayton, Ohio (USFA, 1987) (Additional file 1). Studies on wildland fires and associated

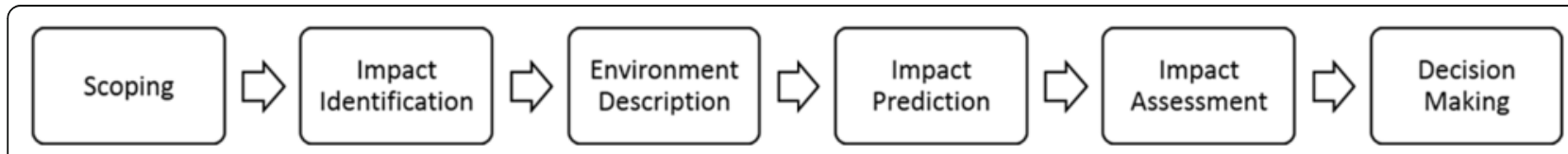

Fig. 1 Progression of steps conducted for environmental impact assessment (CRC, 1999) 
with environmental impacts. Wildland fires are extensively studied, not only for their immediate effects, but their long-term effects as well. Effects of burning out a portion of the forest range from increased erosion and problems for water quality, to habitat degradation.

Standards and guidelines were reviewed, including environmental- and fire-focused documents. Of particular interest is the ISO Standard 26367, Guidelines for Assessing the Adverse Environmental Impact of Fire Effluents. ISO 26367 Part 1 (Additional file 1), a published standard, provides an overview of the subject area, including describing fire effluents, what the environmental impacts of the fire effluents are, how intervention can be considered, and how to assess the overall environmental impact. ISO 26367 Part 2 (Additional file 1), currently at the Committee Document stage (unpublished and not publically available), will likely include details on toxic products of combustion and means to sample them in-situ, when published.

Studies which outline different techniques for quantifying the impact of fire from different products, with and without fire retardants to understand the impacts at a micro-level, were also considered. One of the most prominent is the "Fire-LCA", developed by SP in Sweden in the early 2000s (Andersson, et al., 2004) (Additional file 1). Hamzi has done a significant amount of research to look at different products and quantify what the life-cycle costs of the product would be if the product was to be impacted by a fire at any point over its life (Hamzi et al. 2008).

Studies associated with sustainability and fire protection identified cost-benefit issues associated with using fire protection system as a way to reduce the environmental cost of fire. These include an FM Global (FM Global, 2010) study showing the sustainability of sprinkler systems in residential buildings both in terms of water savings for extinguishment as well as limiting the overall environmental effects of a fire, a BRE study (BRE Global, 2013) which determined cost savings associated with sprinklers in small, medium, and large scale warehouses over the lifespan of a building, and a BRANZ study (BRANZ, 2012) which considered sustainable construction and fire issues. Through the literature survey it was found that a wide range of impacts to a diverse biological spectrum, including people, have been investigated. It was also found that quantification can be local or global, species or system related, and narrowly or broadly encompassing. To bound this research, it was ultimately decided to limit review to ecological impact assessments, with human health impacts not being studied.

Likewise, fires occur in buildings of all sizes and uses, and it can be difficult to quantify the impact, especially given the range and uncertainty around knowledge of the contents of buildings. Since contents are largely not regulated by code, it is not easy to compile information required to assess potential impacts. This is an area where further study is warranted.

Ultimately, it is of interest to investigate how environmental impacts of fire might aggregate: locally, regionally and globally. While data limitations, such as outlined above, resulted in aggregation of impacts being omitted from this study, a conceptual approach as to how it might be conducted is illustrated in Fig. 2. It is suggested that as more data on fires and impacts become available, such an approach to assessing aggregated impacts can be developed.

\section{Historically significant fires}

Many fires have an impact on the environment because of the relative ease of transmission of harmful chemicals to the nearby environment. Table 1 contains a list of fires with significant impacts on the environment or that represent a fire where there was a particular effort to address the environmental impacts of the fire and firefighter activity. Possibly one of the most critical fires to identify is the fire in the Sandoz chemical warehouse in Basel Switzerland. This fire is important to the history of the environmental impact of fire because the result of the fire was to pollute the Rhine River, causing an international incident between Switzerland and the countries downstream of the pollutants. The next significant fire to discuss is the fire at the Sherwin Williams paint factory in Ohio, USA. The facility was located very close to an aquifer that 400,000 people needed for drinking water. The incident commander made the decision not to apply water to the fire because the effects of the air pollution was considered to be less than that of polluting the aquifer.

\section{Impacts}

If an environmental event causes an impact to the ecology, generally it will affect a large area and affect the ecology of that area. This is the more likely outcome of a fire event. One can break the impacts into pathways, over which the hazards travel from the source to the target. The pathways are environmental pollution through water, air, land or noise pollution. (CRC, 1999). Hazards that can be experienced from a fire include general pollutants/indicators, metals, particulates, polycyclic aromatic hydrocarbons (PAHs), chlorinate dioxins and furans, brominated dioxins and furans, polychlorinated biphenyls and polyfluorinated compounds ((e.g., see ISO 26367-2), (Turekova \& Balog, 2010), (Simonson, et al., 2000) (Additional file 1), (Simonson et al. 2001), (Andersson et al. 2003)). From this list we can see that there are a wide variety of chemicals and particulates emitted during fires that have been identified as having a negative impact on the environment. It is necessary to identify and understand which of these substances will have an impact on the three 


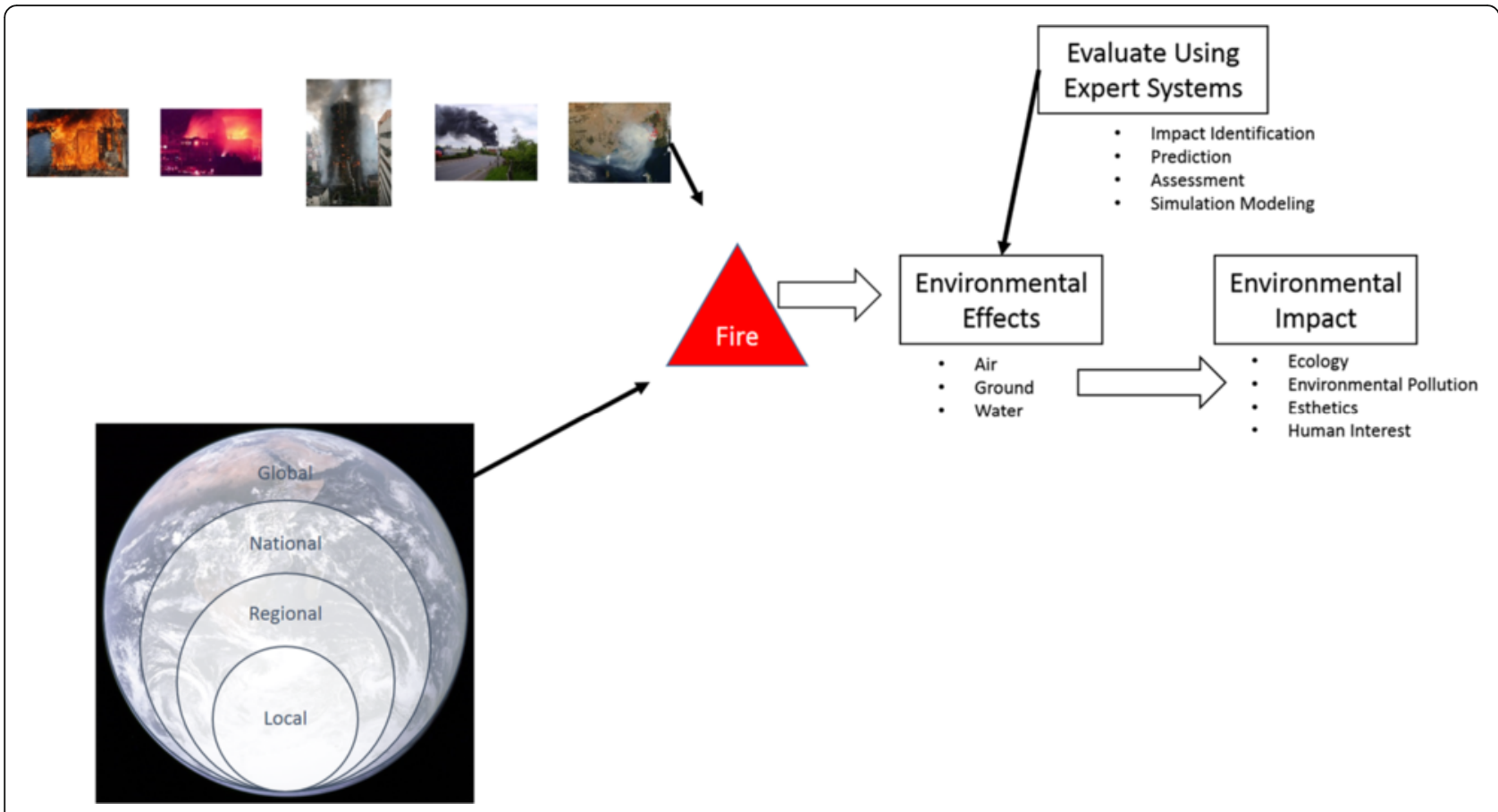

Fig. 2 Concept for aggregating the environmental impact of fire

major environmental receptors of concern: the atmospheric, aquatic and terrestrial environments. However, quantification of the impact is difficult, as challenges exist in identifying and appropriately sampling these substances during and following a fire event. In addition, the exposure time and persistence in the environment can play a role.

The fire effluents may or may not make an impact on the environment depending on the duration of exposure, the means of transmission to the environment, and the susceptibility of the receptor. A clear distinction to differentiate impacts is the differentiation between short term and long term, where short term impacts are considered to occur over a few hours or a few days, at most. Long term impacts are impacts beyond immediate, short term impacts.

Short-term environmental impacts from exposure to fires pertain mostly to the local environment within the fire plume zone and water run-off zone. The nature of the impact(s), the exposure pathway(s), and the time period for which this condition is expected to exist shall be reported and should at least include the following contaminants: nitrogen oxides $\left(\mathrm{NO}_{\mathrm{x}}\right)$, sulphur oxides $\left(\mathrm{SO}_{\mathrm{x}}\right)$, metals, halogenated acids (HX) and particulates ((Andersson, et al., 2004), (Simonson, et al., 2000), (FM Global, 2010), (Marlair et al. 2004), (USDA, 2002)) (Additional file 1).

The long term environmental impacts, resulting from hazards from fire will be considered impacts that are not immediately felt or recognized. An example of this is the impact of erosion after a wildfire because it happens months to years after the fire had been contained. These effects are focused in the location(s) where the fire occurred or a relatively short distance away, but there are exceptions based upon the pathway that the hazards might take. The following pollutants have been identified as having some long term impacts: metals, polycyclic aromatic hydrocarbons (PAH), polychlorinated dibenzofurans (PCDF) \& polychlorinated dibenzodioxins (PCDD), polybrominated dibenzofurans (PBDF) \& polybrominated dibenzodioxins (PBDD), polychlorinated biphenyls (PCB) and perfluorinated compounds (PFC) ((FM Global, 2010), (EPA 2008), (Blomqvist, 2005), (Andersson, et al., 2004), (Simonson, et al., 2000)).

A critical piece of the transmission is the transport medium. A generalization below is intended to provide guidance to non-experts when determining what the major impact of concerns are.

\section{Fire effluents in the air}

The fire plume will entrain products of combustion upward due to buoyancy, where it will spread based on prevailing wind conditions. Research has shown that the emissions of the toxic and exotoxic species are often involved in the plume as the inorganic gases, volatile organic compounds (VOCs), the Polycyclic Aromatic Hydrocarbons (PAHs), and the dioxins. The species that are lofted by the plume will be fairly light. The main hazard of these gases are the toxicity of the contents and the susceptibility of the receptors. (USDA, 2002) For example wildfires often will emit particulates that consist 
Table 1 List of fires important to the study of the environmental impact of fire $(I S O, 2011)$

\begin{tabular}{lll}
\hline Date & Location & Description \\
\hline 1962-Present & Centralia, PA, USA & Coal mine fire that has been continuously burning causing a large majority of the town to \\
& evacuate. Currently there are less than 15 residents still in the town. The fire is extremely difficult \\
& to reach and extinguish, though many attempts had been made. The environmental impacts of \\
& this fire is the air pollution, greenhouse gas emissions, vegetation die-off. (Brnich \& Kowalski-Trakofker \\
& 2010) (Nolter \& Vice, 2004) (Pennsylvania Department of Environmental Protection, 2013)
\end{tabular}

February 1982 Yorkshire, UK

November 1986 Basel, Switzerland

May $1987 \quad$ Northern China \& Southern Russia

October $1987 \quad$ Nantes, France

June 1987 Ohio, USA

June $1988 \quad$ Tours, France

February 1990 \& Hagersville, Canada and SaintMay 1990

1991

Kuwait

July $1992 \quad$ South Bradford, UK

October 1995 Wilton, UK

December 1995 Somerset West, South Africa

June $2001 \quad$ Venizel, France

January 2002 Murcia, France
Fire at a warehouse in Yorkshire grew very quickly. The fire department was provided with Transport Emergency Cards (TREM) relating to Herbicides and Octylphenol, however the fire grew very quickly. The fire department attacked the fire with water. The runoff caused widespread major pollution of the local water and land. (Health and Safety Executive, 1993) (Nelson, 2000)

Sandoz chemical warehouse was a fire that triggered the study of the environmental impacts of fire worldwide. 10 years after the fire, the eels in the Rhine were not consumable (New Zealand Fire Service, 2001) (McNamee, 2014).

The Black Dragon fire burnt a total of $72,884 \mathrm{~km}^{2}$ (28,141 sq mi) of forest along the Amur river, with three million acres (4687.5 mile ${ }^{2}$ ) destroyed on the Chinese side. (Salisbury 1988)

A chemical warehouse storing inorganic fertilizers suffered a major blaze due to self-sustained decomposition of $20 \mathrm{t}$ of $\mathrm{N}-\mathrm{P}-\mathrm{K}$ products, releasing a massive toxic plume that eventually dispersed over the ocean. Some 15000 people were evacuated as a precaution. Afterwards, an experimental assessment of the plume toxicity confirmed the toxicity of the effluents (Marlair et al. 2004).

Sherwin Williams paint warehouse stored almost 1.5 million gallons of paint. Significant because warehouse was located over several aquafers. Also notable for the fact that the fire service assessed the risk of the extinguishment vs the risk of polluting the aquifer. (USFA, 1987)

Known as the "Protex" fire, this chemical fire spread vigorously due to the close proximity of flammable and toxic products. The plume zone was some $30 \mathrm{~km}$ long and $12 \mathrm{~km}$ large (fire plume zone) and provoked major pollution of the river Brenne (Marlair et al. 2004).

Two of the numerous large-scale tire waste fires that have taken place in North America. Tire fires last several days to several months, lead to massive air, soil and water pollution, and extreme difficulties in fire-fighting. Evacuation of people is required in some cases, and fresh water sometimes disrupted for long periods. Lessons learned led to the production of useful guidelines in North America and Europe (Marlair et al. 2004).

As a result of the Iraqi invasion of Kuwait, oil wells were systematically damaged through the use of explosives, resulting in uncontrolled gas and oil blowout fires in some 700 wells. The environmental contamination by both oil leakage and fire gases was severe, in relation with the tremendously important and long-lasting releases of pollutants (equivalent to some 7400000 bbls/ day) that have affected air and soil, according to the NIST evaluation report from 1994. (EPA, 1991) (Additional file 1).

A major pollution of the aquatic environment resulted from the run-off of some $16000 \mathrm{~m}^{3}$ of contaminated water used to fight a fire in the plant of a chemical manufacturer: the UK reference in matters of pollution by contaminated water run- off in fresh water streams. The origin was the proximity of storage of incompatible chemicals. (New Zealand Fire Service, 2001) (Health and Safety Executive, 1993)

Polypropylene warehouse fire on a chemical complex, which raged for $12 \mathrm{~h}$, due to fault in the lighting system. Some of the fire protection features did not operate correctly as a result of the smoke ventilation system prevented the fusible links of the fire doors to close. The incident generated large quantities of smoke, but an on-site risk assessment considered the smoke non-toxic. (Health and Safety Executive(b), 1995)

Massive fire of a sulfur stockpile used by three different companies in industrial applications. A unique proof that fire toxicity is a lethal threat, even in the open environment (Marlair et al. 2004).

A fire accident in a paper mill containing polychlorinated biphenyl (PCB) transformers presented considerable difficulties for emergency response management, and required the medical survey over a year of some 100 people (including journalists), liable to have suffered some exposure to dioxins and PAHs. A case study which reveals that, until the phase-out of a banned product is fully effective, the threat remains. An instructive report was produced on the aftermath of the fire and made public by the French authorities (Marlair et al. 2004).

Large release of toxic effluents arising from a warehouse storing inorganic fertilizers (NPK) in a scenario quite similar to that which occurred in Nantes in 1987. 
Table 1 List of fires important to the study of the environmental impact of fire (ISO, 2011) (Continued)

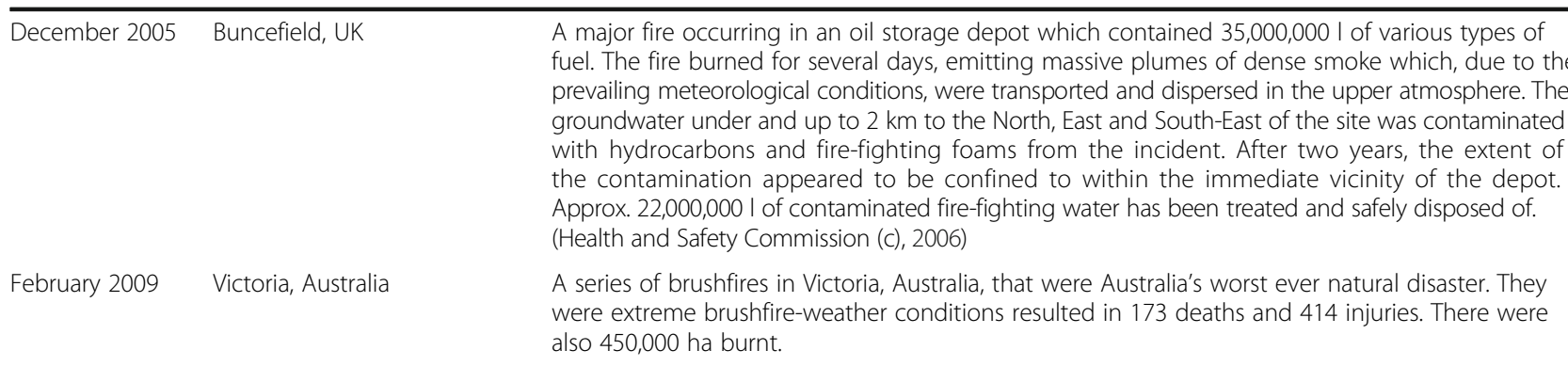

of soot and smoke particles. These particles are not toxic or extremely dangerous to healthy populations, but are dangerous to susceptible populations such as those with asthma or old populations.

\section{Fire effluents in the water}

The impact of the fire effects on water have already been shown to be disastrous in the case of Basel Switzerland. Fire is commonly extinguished with water, although other agents (e.g., surfactants, foams) may be used depending on the type of fire. If proper containment and treatment of the run-off is not achieved, there is an opportunity for it to travel and disrupt a proximate natural water way. Many chemicals and possible pollutants are soluble or can be carried by water to a natural source. One of the more non-specific effluents is the fire effluents of any of the products that a building or warehouse has on-site, in addition to Polycyclic Aromatic hydrocarbons (PAHs), volatile organic compounds (VOCs), hydrocarbons, dioxins, metals, ammonia, and suspended solids that are also likely in the materials at the site (USDA, 2005).

\section{Fire effluents in the terrestrial environment}

The impact of fire effects on the terrestrial environment is less of a short term hazard, but might have long term exposure concerns. A distribution of the effluents to the terrestrial environment can be a primary pathway, as well as a secondary pathway where effluents would be thrown from the plume down to the ground. A critical part of the identification of the effluents will be to examine whether there are any hazardous materials stored on site as well as any extinguishing agents used.

\section{Quantification of the effluents}

Sampling can be conducted a variety of ways and the method and level of analysis is very goal oriented. For example, the United States helped Saudi Arabia and Kuwait analyze their needs for sampling for the duration of the Kuwaiti oil fires. In the Kuwait, initial sampling was conducted to detect the concentrations of Sulfur
Dioxide or Hydrogen Sulfide as well as the level and size of particulates. After the initial modeling exercise, then steps were taken to retrieve data from the fire plumes, first using methods immediately available and then by including discrete sampling via ground locations or aircraft (EPA, 1991). This included taking immediate steps to collect and analyze meteorological data as well as visual observations via satellite. Then as the fire expands in scope a sampling network is built up to collect and analyze the effluents from the fire.

The Kuwait Oil fires was a large scale, long duration environmental event. This gave the EPA time to coordinate and position the wide range of sampling methods used. Figure 3 displays a visual of the expanding complexity and expanding timeline of events during an event.

Initially visual observations must be made using observational skills or with a satellite depending on the size and location of the event. An initiating event comes with a high degree of randomness and unpredictability. As a result, the most time-efficient methods of sampling should be applied. The next step in the data collection timeline is the use of meteorological information to predict possible effects of weather in the dispersion of any environmental impacts. This should include visual cues, satellite imagery and predictive models. Knowledge of the wind direction or precipitation would be useful to determine the fire effects that move and travel. The last step and the most complex step in the sampling process is setting up devices to collect data on different fire effluents that can be used to track concentration and toxicity. This step is highly dependent on the goals and objectives of the entity doing the sampling.

For example, if this timeline is going to be used by fire departments responding to a residential structure fire, they will first visually observe the event. As a secondary step, they will take into account the wind or precipitation, but they most likely will not set up any sampling.

Alternatively if a forest fire is in its incipient stage of growth, satellite imagery is used to pinpoint a location for visual confirmation. The meteorological model is then incorporated into the satellite imagery to create a predictive fire growth model. 


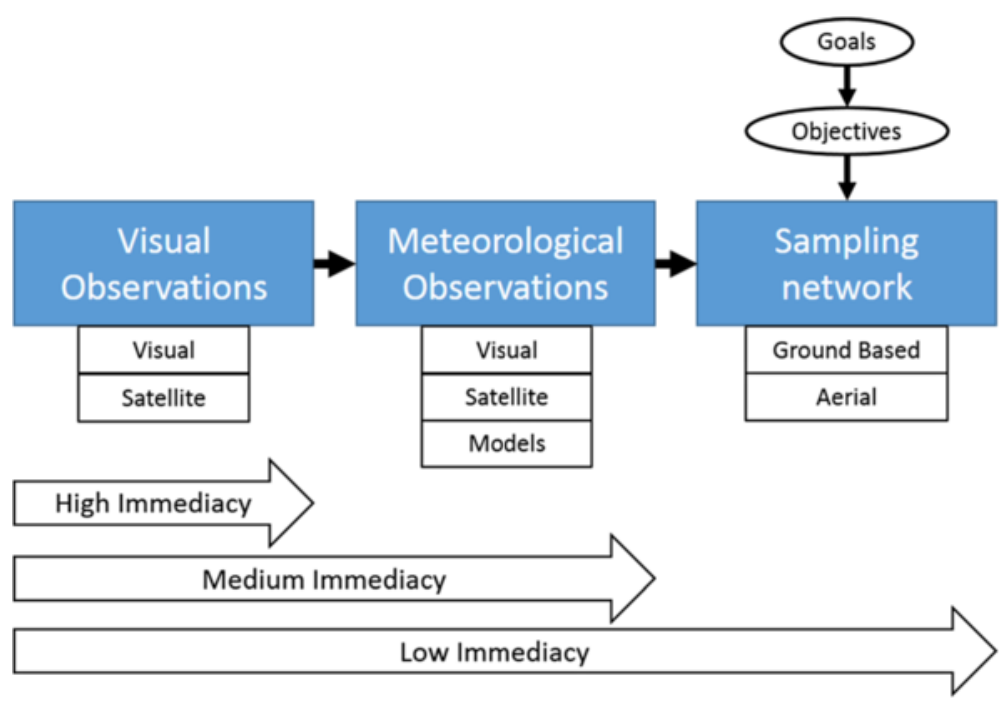

Fig. 3 Figure describing the expanding complexity of data collection during an event

\section{Calculations}

To calculate the effects of fire, the fire protection industry has many equations and models that are used for fire dynamics applications. For example, NIST sent a team to correlate the heat release rate of the crude oil wells to the flame height during the Kuwait oil fires (Evans et al. 1994). Similarly the EPA has techniques used to gauge the environmental effects of certain events. Planes were used to take air samples to determine how widespread the damage was. Regional temperatures were collected to determine the effect on temperatures that the reduced sunlight had on the region. Air monitoring stations were setup in the major cities in the area to measure the amount of pollution in the air, particularly measuring PM-10, $\mathrm{SO}_{2}$, and $\mathrm{NO}_{2}$. This sampling effort, combined with the statistical calculation techniques used, led to the conclusion that the problem was limited to a small area around the oil wells.

There have been few studies that quantify the impacts of fire over a wide area and/or aver a lengthier period of time. Blomqvist (2005) performed an estimate of the total amounts of PCDD/F, PAH, and VOC that were emitted from all fires in Sweden during 1999. This was done by estimating the amounts of materials involved in the building fires and fires in specific objects. These then were assigned emission factors for the materials and the objects. This study showed that there is a wide range of results because of the variability involved. The results for PDDD/F garbage fires yield extremely high emissions of PCDD/F, with between $210-870 \mathrm{mg}\left(7.4 \times 10^{-}\right.$ $\left.{ }^{3}-30.7 \times 10^{-3} \mathrm{oz}\right)$ TEQ being emitted. For PAH and VOC dwellings contained the highest emissions, most likely because of the much higher number of fires. These were measured to be $4.8 \mathrm{t}$ of $\mathrm{PAH}$ and $65 \mathrm{t}$ of
VOC emitted from dwelling structures to the atmosphere.

For the emission from dioxins (PDFF/F), the emissions from fires are a significant source and are about equivalent to the emissions from traffic and municipal waste combustion.

\section{On site $\mathrm{CO}_{2}$ release data}

The United States Department of Energy (US DOE) has developed data that allows calculation of the embodied energy of different building assemblies (DOE, 2011). The utility of this data will provide information for what the embodied energy and the $\mathrm{CO}_{2}$ equivalent. The availability of this data provides fire departments and other pertinent parties with the information to calculate the amount of $\mathrm{CO}_{2}$ that is release based upon the square footage of materials burned. A recommendation is to explore the use of data revealing the embodied $\mathrm{CO}_{2}$ and how it relates to buildings and building contents. That connection should then be used in conjunction with fire statistics to estimate the approximate $\mathrm{CO}_{2}$ released from fire.. One of the challenges is that there is little data to verify any estimate that could be made, however laudable efforts by work at FM (FM Global, 2010) and Lund (Andersson et al. 2003) (Andersson, et al., 2004) (Simonson et al. 2001) (Simonson, et al., 2000) provide some experimental fire testing results.

Figure 4 shows the general connections between the different data sets needed to develop hypothesis on the amount of $\mathrm{CO}_{2}$ resulting from fires. The first step is to collect the for the region to analyze, whether this be a state, country, or the globe. Specifically the number of fires that have occurred, the percent of the building each fire has burned, the occupancy type, and the 


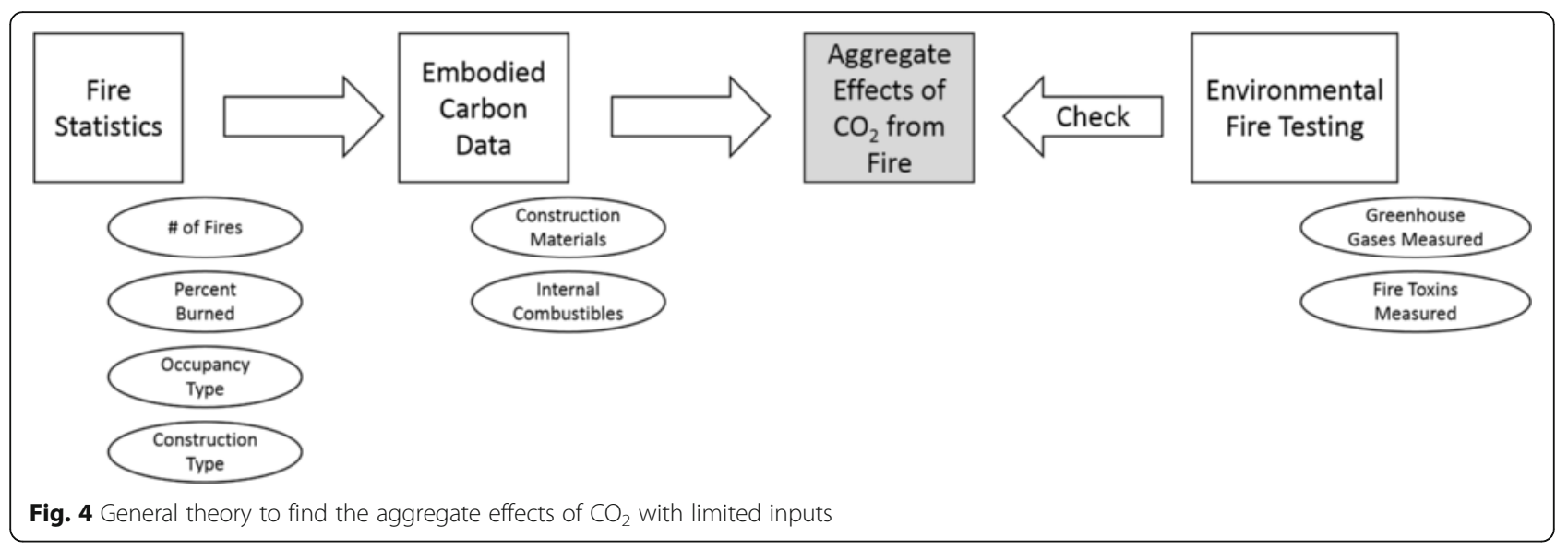

construction type would be the minimum amount of data that could be used for an estimate.

These data points are helpful to determine two things about the fires statistics which is the total area burned and what materials were burned. Once those items are determined then the embodied carbon data can be used to find the total embodied carbon that was destroyed by the fire. The actual testing that was mentioned above should be compared to check the results.

\section{Impact prediction}

There are numerous methods used to predict the impact on the environment of both project based studies and non-project based studies. A study done by the Water Resources Council in 1983 developed several approaches which can be used to predict impacts (CRC, 1999):

a) Adoption of forecasts made by other agencies or groups

b) Use of scenarios based on differing assumptions regarding resources and plans

c) Use of expert group judgment via the conduction of formalized Delphi studies or the use of the nominal group process

d) Extrapolation approaches based upon the use of trend analysis and simple models of environmental components

e) Analogy and comparative analyses which involve the use of look-alike resources and projects and the application of information from such look-alike conditions to the planning effort

Forecasts are most relevant for wildland fires. Wildland fires can be reasonably predicted by groups such as the United States Forest Service (Wildland Fire Assessment System, 2010). Different models have been developed to use remote sensing, lighting sensing, and in-situ observations to forecast the locations where burning will be more likely.

Such tool can explore hypothetical and real-life wildland fire scenarios to output quantified data of the predicted impacts. There has been extensive research and innovation in the field of modeling and remote sensing. As the cost of computational power as well as the cost of remote optics decreases, it becomes easier to get a well-defined representation of wildland fires. With the inputs listed below (see Table 2), the outputs can be found through a modeling exercise. This calculation builds on the research that the United States Department of Agriculture (USDA) and the USFS has done to characterize and quantify the types of forest and vegetation to aid in their predictive capabilities for where and how severe a wildfire will be (Clinton et al. 2006) (Additional file 1).

While the inputs to this predictive model may look rather complex and difficult to acquired, it is less difficult then would be thought. Geographic Information System data (GIS) is a technology that is used to capture, manipulate, analyze, and manage all types of special data. (CEGIS 2014). The vegetation data has been implemented into a series of growth models and will act to predict the types of special vegetation. (USFS 2013). Weather and climatic data is also provided through the National Oceanic and Atmospheric Administration and they specifically have a

Table 2 Inputs and outputs for wildfire modeling

Inputs
- Geographic Information System (GIS)
data
- Vegetation Data
o Fuel Data
○ Duff
○ Litter
○ Herbs
○ Shrubs
○ Tree Regeneration
○ Live Branch-Wood
○ Live Foliage
- Weather Condition Data
- Fire Perimeters

Outputs (pounds)

- 10 um Particulates

- $2.5 \mu \mathrm{m}$ Particulates

- Carbon Dioxide $\left(\mathrm{CO}_{2}\right)$

- Carbon Monoxide (CO)

- Methane $\left(\mathrm{CH}_{4}\right)$

- Non-Methane

Hydrocarbons

- Ammonia $\left(\mathrm{NH}_{4}\right)$

- Nitrous Oxide $\left(\mathrm{N}_{2} \mathrm{O}\right)$

- Oxides of Nitrogen $\left(\mathrm{NO}_{x}\right)$

- Sulfur Dioxide $\left(\mathrm{SO}_{2}\right)$

- Fire Perimeters 
focus on the effects of weather on fire (Bussum, 2013). Finally, the use of remote sensing has allowed for stakeholders to have more information about the fire and its movements using multiple different sensing technologies increases the accuracy of the model (USFS 2015).

The affected locality of the environmental impact of a fire, or an aggregation of multiple fires should both be identified as part of determining the impacts of fire (see Fig. 5). Individual buildings provide the information necessary to look at the environmental effects of the fire. Those affects, can then be aggregated to provide the aggregated environmental effects in a region, nation or the world depending on the data available.

The fire problem in the United States includes $1,240,000$ fires resulting in 3,240 civilian fire fatalities and an estimated $\$ 11.5$ billion in property loss (Karter, 2014). Data from sources as the US Census, National Association of Home Builders (NAHB) and Commercial Building Energy Consumption Survey (CBECS) can be used to estimate numbers of buildings of different types. We can then look to data to estimate types of construction material and contents. This is an example of how, in the United States, available data on the number/types of fires presents the possibility for developing an 'order of magnitude' approach to the aggregate environmental impact of fire.
Prediction of the impacts based upon the relative size of the fire as well as the locations is described in our taxonomy two ways. First, there are examples that clearly demonstrate that a single fire event creates an impact on the local environment, the regional environment, the national environment, and the international environment. An example to demonstrate this principle is the Sandoz Chemical Warehouse fire in 1986. The fire represents a single event that had an impact across every definition of locality, as a result of hazardous runoff being distributed via the Rhine River. (Holemann, 1994) (Additional file 1).

Further exploration will be necessary to determine the specific effects at a local, regional, national, and international level. The links below, provided in the full bibliography, provide useful information for global data. Further study of a global fire problem is necessary to conduct any aggregation estimates at a global scale.

- Lloyds Insurance Group (Lloyds, n.d.)

- Geneva Association (Geneva Association, n.d.)

The extent to how the buildings involved in a fire event have an impact on the environment will be determined by the availability of flammable items, the hazard of the toxins and the risk of a fire event occurring. For example, a single residential fire results in different

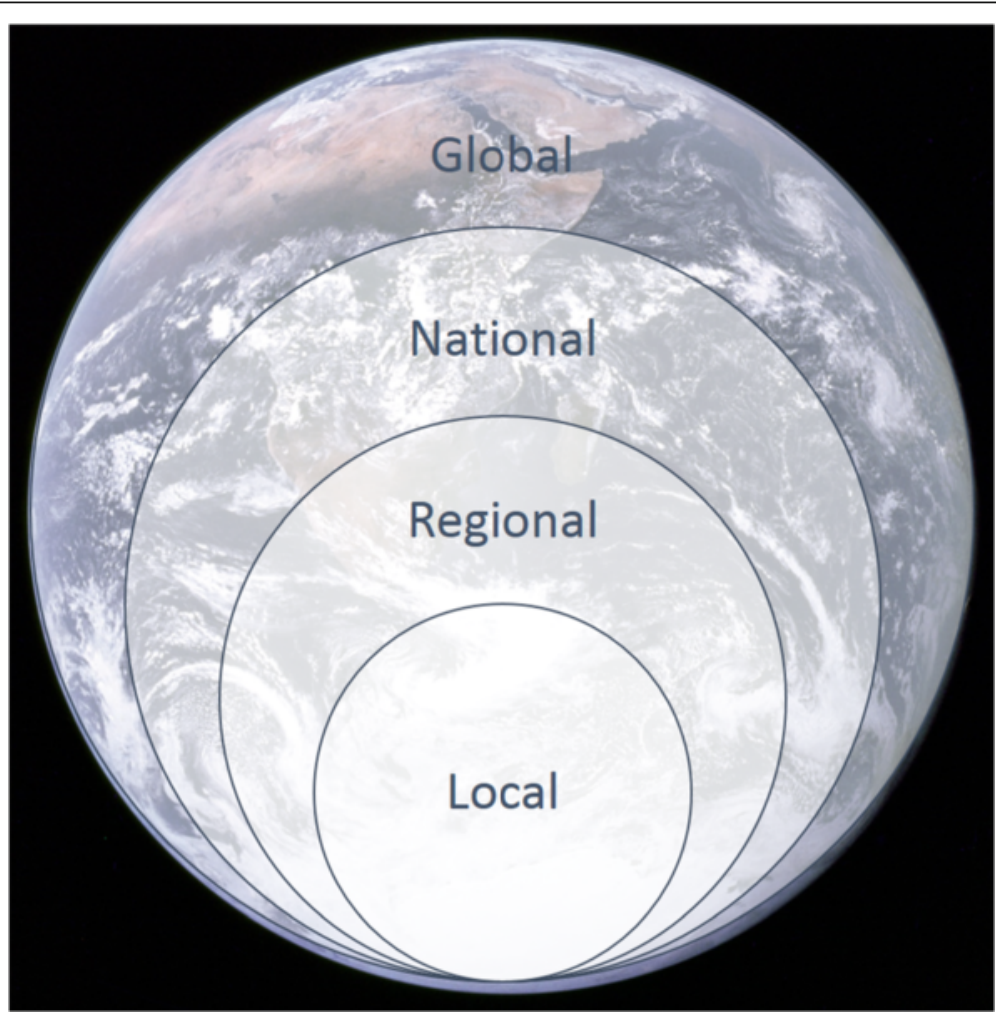

Fig. 5 The aggregate effects of fire effects the population and the environment at every locality 
environmental effects than a single industrial plant fire or a single wildfire.

The information for each building is both specific and non-specific, meaning that each building has a defined maximum amount of hazardous materials allowed to limit the hazard to occupants, first responders, and the environment. It is difficult to identify exactly what the building will contain because the contents of each building are unique. Estimates based on previous research and fire statistics can be used to find an order-ormagnitude approximation. However, it is challenging to bound this problem for industrial and high-hazard structures, which may contain a large array of different chemicals and toxins.

One way to bound the problem is through the definitions of each occupancy, the construction type and the limits of materials allowed in the Building and Fire Codes (ICC (2012a)) (ICC (2012b)) (NFPA, 2012). From the ICC Fire Code and the NFPA Fire Code, there are limits to the amount of combustible, explosive and flammable materials. In addition it also limits the maximum amount of hazardous material allowed. This acts to limit the amount of hazardous materials, but also alerts the fire department to any increase beyond what they would typically see. This allows the first responders to be cognizant of the hazard and pre-plan ways to mitigate the hazardous condition.

\section{Fire statistics in the US}

The fire events in the United States is reported on by the NFPA. Between the years of 2007-2011 there were approximately 498,500 fires per year (NFPA 2013a, b). These statistics are important to characterize the environmental impact of fire. To use the statistics from the United States, and from other countries, it is important to note that just accounting for the number of fires will give an over estimation of the impacts, whereas accounting for the property damage will more closely equate to the impacts to the environment.

The fire problem as it relates to the environment can be largely identified by the direct property damage information. The higher effluents to the environment and higher embodied carbon amount released from the structures were assumed as more property damage is present. For example, FM Global (FM Global, 2010) conducted a study to compare the environmental impacts of non-sprinklered residential buildings versus sprinklered residential buildings. One of the criteria was the measured amount of greenhouse gases that were produced. This is one good source that could be used to estimate the greenhouse gases that would be found in a typical residential fire.

It is estimated that an average of 366,600 home structure fires occurred per year during 2007-2011, causing
$\$ 7.2$ billion in direct property damage per year. (Ahrens, 2013) Of those, the highest number of fire events were in one-to-two family residential occupancies with $52 \%$ of all fire events. The most civilian deaths also occurred in one-to-two family residential occupancies fires, accounting for 2,165 deaths or $77 \%$ of the civilian deaths. The cost of the direct property damage in the United States was $\$ 6.0$ billion, with $56 \%$ of the damage having occurred in one-to-two family residential occupancies. (NFPA 2013a, b)

The department of energy reports that the total building stock went from 108.8 million households to 114.2 million households between 2005 and 2010. (DOE, 2011) Therefore, it is estimated that about $0.32 \%$ of the building stock would have a fire in it every year.

Buildings occupied by business are typically found in low rise offices up through super-tall buildings. The contents of the business occupancies will generally be the same, with the difference mainly in the total size of the building and the construction types.

In high-rise buildings, between 2007 through 2011, there were over 46 civilian deaths and 530 injuries. The approximate direct property damage was estimated to be \$219 million. High rises are defined as buildings with their highest occupied floor as being $75 \mathrm{ft}$ above the lowest level of fire department access (ICC (2012a)). The most common occupancies of a high-rise building is apartment buildings, hotels, office buildings, and facilities that care for the sick. The level of protection in a high-rise building is usually greater because of the additional fire safety measures required by the code (Hall, 2013).

About 42,800 fires in industrial and manufacturing properties were reported during 2006-2010 in the U.S. fire departments per year. Of those, 30,200 were unclassified fires, 4,100 were vehicle fires, and these events caused $\$ 951$ million in property damage per year. (Evarts, 2012)

The NFPA tracks structure fires and compiled the following list of wildland fires (see Table 3) that have occurred in the United States. The cost of the largest wildfires in the United States has grown tremendously in 20 years. (NFPA 2013a, b). The cost of combating wildfire in the 2014 was $\$ 1.5$ billion dollars (National Interagency Fire Center, 2014).

The national interagency fire center (NIFC) is an organization who serves as a coordinator for wildland fire events throughout the United States. NIFC is responsible supporting incidents around the country at all levels of risk and as such it can leverage its own, and its partner organizations, advanced ability to track and respond to wildland fire events. This agency develops the teams that are necessary to respond to a wildland fires and sets up mobile response units. Over the past 10 years 
Table 3 Large loss wildland fires in the United States by dollar amount (NFPA 2013a, b)

\begin{tabular}{lll}
\hline Fire & Loss in Year Fire Occurred & Adjusted Loss in 2012 Dollars \\
\hline 1. Oakland Fire Storm (wildland/urban interface) Oakland, California Oct-91 & $\$ 1.5$ billion & \$2.5 billion \\
2. The Southern California Firestorm* San Diego County, California Oct-07 & $\$ 2.0$ billion \\
3. "Cerro Grande" Wildland Fire (wildland/urban interface) Los Alamos, New Mexico May-00 $\$ 1.0$ billion & $\$ 1.3$ billion \\
4. "Cedar" Wildland Fire Julian, California Oct-03 & $\$ 1.1$ billion & $\$ 1.3$ billion \\
5. "Old" Wildland Fire San Bernardino, California Oct-03 & $\$ 975$ million & $\$ 1.2$ billion \\
6. Southern California Wildfires of November* Sacramento, CA Nov-08 & $\$ 800$ million & $\$ 853$ million \\
7. "Laguna Beach Fire" (wildland/urban interface) Orange County, California Oct-93 & $\$ 528$ million & $\$ 838$ million \\
8. Wildland Fire* Florida May-June, 1998 & $\$ 395$ million & $\$ 555$ million \\
9. Forest Fire Cloquet, Minnesota Oct-18 & $\$ 35$ million & $\$ 532$ million \\
10. "Paint Fire" Goletta Wildland/Urban Interface Santa Barbara, California Jun-90 & $\$ 237$ million & $\$ 416$ million
\end{tabular}

*Includes multiple firess

the average number of wildfires in the United States per year is 6,964 fires, with an average of 183,481 acres burned every year. The most severe year in the last 10 years was in 2006 when 543,465 acres burned (NIFC 2014).

\section{Impact analysis}

Impact analysis includes the different set of analyses which are conducted to determine what the severity of the impacts will be and how they might manifest themselves. Three types of analysis are presented as the most common methods for understanding the impacts. When conducting any type of analysis like this there is a specificity and data problem, meaning that, to fully conduct the analysis requires a significant amount of information and a clearly defined focus for the analysis.

Table 4 represents generalized analysis inputs and outputs. Ranging from simple and course to sophisticated and refined. The difference between the different types of analysis will be cost, where cost is determined based on both economic costs and time costs. The usage of different analysis changes based upon what is required from the analysis. For example for an incident commander during a fire, the simple and course method will be chosen because of the immediacy of the situation and the low amount of resolution needed as well as the clear focus. A full life cycle analysis would require a sophisticated and data-rich (refined) study and therefore it is a

Table 4 Simple cost benefit square for understanding environmental impacts

\begin{tabular}{lll}
\hline & \multicolumn{2}{c}{ Output } \\
\cline { 2 - 3 } Input Data & Coarse & Refined \\
\hline Simple & Minimize Cost & Minimize Time \\
Sophisticated & Minimize Expense & High Cost \\
\hline
\end{tabular}

very costly study both in terms of time and information needed.

The life cycle analysis (LCA) is a method that maps the lifecycle of a product, identifies the stages of production, use, and end-of-life processes. The LCA is a powerful tool to show the environmental costs of the lifecycle of a product, process, or policy. This tool is most commonly used in to look at individual products and processes, however recent interest by different industries, has led to the creation of tools to study a building as a whole.

In addition, the fire community has their own version of an LCA, called the Fire-LCA. The methodology was developed specifically to identify the stages in the products lifecycle where a fire will occur (Simonson et al. 2005). The Fire-LCA process is primarily the same process as the typical LCA process with the difference being that it includes modules to account for accidents, like fires. It also includes modules that recognize the extent of the damaged area, the fire extinguishment and the replacement of damaged materials. The methodology was developed at SP in Sweden (Simonson, et al., 2000) especially by Simonson, Blomqvist, Andersson. The effort resulted in a comprehensive guidance framework for conducting a Fire-LCA (Andersson, et al., 2004) as well as several full case studies (Simonson, et al., 2000), (Simonson et al. 2001), (Andersson et al. 2003).

The relative effort that is required for the life cycle analysis is significant. For example, Hamzi et al. 2008, displays the steps to conduct a life cycle analysis on storage tanks used in crude oil material production. To complete the analysis, statistics on the following are required:

- Type of complex where accidents occurred

- Type of tank contents

- Type of accident \{fire, explosion, spill, etc.\} 
- Cause of Tank Accidents \{lightening, maintenance, failure, etc.\}

- Size of tank

- Fire emissions

To adapt the methods of Hamzi et al (2008) to an analysis of a building, Fig. 6, was developed to show one example of how the life cycle analysis of a building could be adapted to fit into the Fire-LCA method. Conducting this type of analysis, especially in the United States, is made simpler by the fact that there are several tools used to calculate the life-cycle costs of materials and practices, however this is still a very complicated and involved process.

The interest in sustainability in recent years, has led to the availability of several tools which to calculate the various values (i.e entrained $\mathrm{CO}_{2}$, energy usage, etc.) important to the environment. The two tools listed below are for informational purposes only, and do not indicate a particular endorsement to any product or tool.

These tools are comprehensive and represent viable ways to produce easy result with little user input. These tools are built to include massive libraries containing information on various building products. For example they have data regarding the embodied $\mathrm{CO}_{2}$ for the most common building components for the totality of the building.

\section{Athena impact estimator}

The Athena Impact Estimator is a spreadsheet tool that is used to quantify the life cycle analysis of a residential building. This is a free tool that is available to the public. The tool was built in part to comply with LEED V4, the International Green Construction Guide (IgCC), the
California Green Building Standards Code, ASTM E2921 - 2013, and EN 15978. The tool is very easy to use for almost anyone and breaks down the process of conducting an LCA by dividing each part of the house into its own section. The data input by the user is typically the materials that are being used and then the number and size of those materials. In this way it can also help show if there are certain materials or sizes that could be altered to create a better lifecycle impact for the building. A similar approach that identifies possibly fire issues would be extremely helpful and powerful. (Bowick et al. 2014).

\section{SiteWise ${ }^{\mathrm{TM}}$}

SiteWise ${ }^{\mathrm{TM}}$ is a stand-alone tool developed jointly by the U.S. Navy, the U.S. Army, the U.S. Army Corps of Engineers (USACE), and Battelle that assesses the remedy footprint of a remedial alternative/technology. This tool includes six main metrics in it calculation (Bhargava \& Sirabian, 2011):

(1) greenhouse gas (GHG) emissions;

(2)energy use (total energy use and electricity from renewable and non-renewable sources);

(3) air emissions of criteria pollutants (total emissions and onsite emissions) including nitrogen $\left(\mathrm{NO}_{\mathrm{x}}\right)$, sulfur oxide $\left(\mathrm{SO}_{\mathrm{x}}\right)$, and particulate matter $(\mathrm{PM})$;

(4) water consumption;

(5)resource consumption (landfill space and top soil consumption); and

(6)worker safety (risk of fatality, injury and lost hours).

This model breaks down the process or activity into blocks over which it can properly identify the above

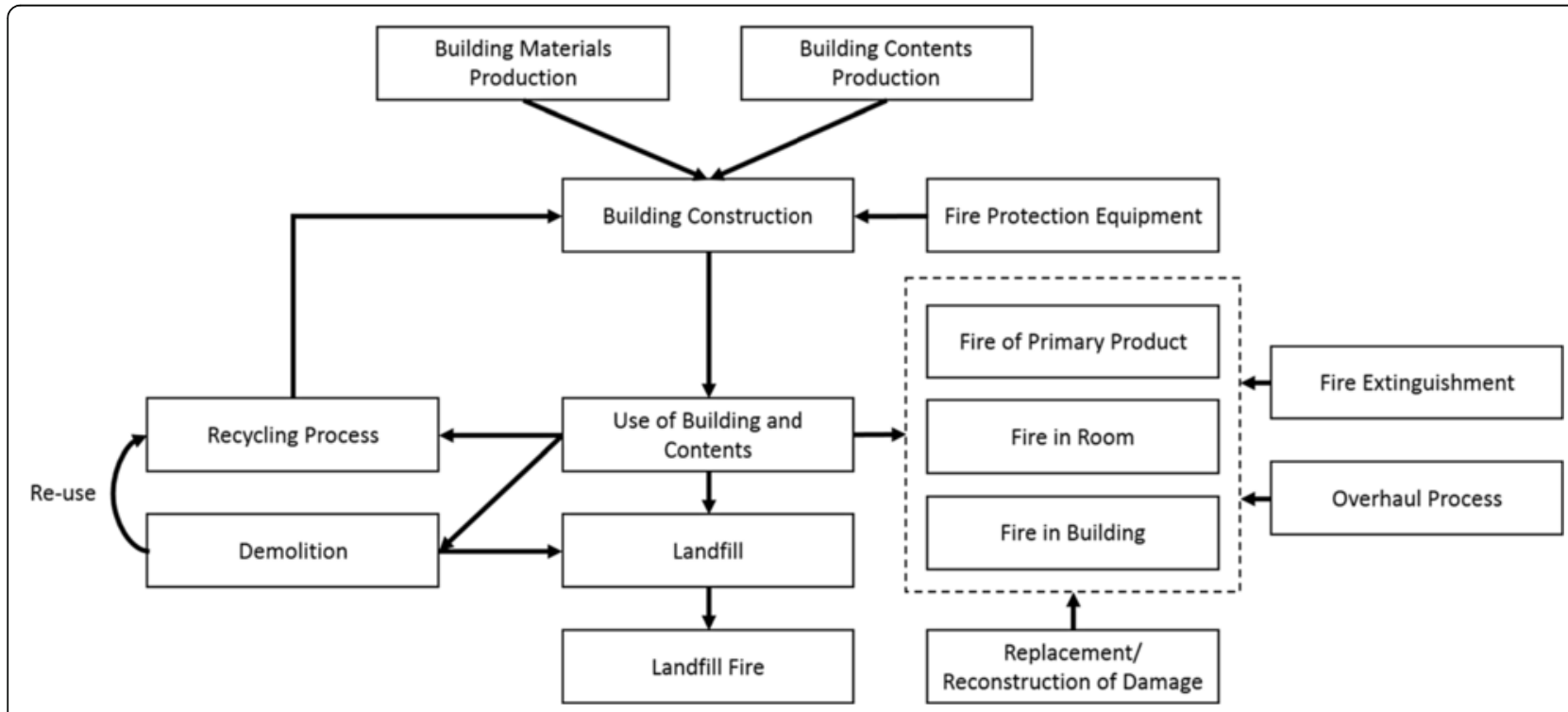

Fig. 6 Method for adapting the Fire-LCA model to buildings (adapted from (Hamzi, Londiche, \& Bourmada, 2008)) 
metrics. In this way it will assign every part of the issue a metric and then sums them together. By approaching this analysis in this way the tool attempts to remove the double counting of environmental factors.

The inputs that need to be considered include (Bhargava \& Sirabian, 2011):

(1)production of material required by the activity;

(2)transportation of the required materials, equipment and personnel to and from the site;

(3)all on-site activities to be performed (e.g., equipment operation); and

(4) management of the waste produced by the activity.

\section{BEES}

Building for Environmental and Economic Sustainability (BEES), is a tool that gauges the environmental performance of building products using a life cycle analysis (LCA) as specified in the ISO 14040 series of standards (Lippiatt et al. 2010). BEES was developed by NIST's Applied Economics Office. This tool incorporates all stages in the life of a product from the raw material acquisition to the recycling or waste management of the product. In addition the economic performance is determined by finding the costs from the initial investment to the cost of repair and disposal. This is done by using the standard ASTM Life-Cycle cost method (ASTM E917 2013).

This is a tool that is would be useful during the construction of building to use as a decision tool. Additionally this tool can be used after an incident to determine what the product's environmental impact would be.

The American standard ASTM E2921-12 provides minimum requirements when conducting wholebuilding LCA for the purpose of attaining building rating system and code compliance. The European EN 159783 is an LCA standard that is increasingly becoming the common method for describing the system boundary of whole-building LCA (Bowick et al. 2014). The ISO standards group TC 207 SC 5 is responsible for Life Cycle Assessment Standards falling under Environmental Management. The fact that LCA has received its own standards committee represents the importance that this tool is seen to have by the regulatory committee (ISO, 2014).

\section{Regulatory Frameworks}

- ASTM E2921: Standard Practice for Minimum Criteria for Comparing Whole Building Life Cycle Assessments for Use with Building Codes and Rating Systems1

- EN 15978: Sustainability of construction works. Assessment of environmental performance of buildings. Calculation method
- ISO 14040: Environmental management - Life cycle assessment - Principles and framework

- ISO 14044: Environmental management - Life cycle assessment - Requirements and guidelines

- ISO 14045: Environmental management - Ecoefficiency assessment of product systems - Principles, requirements and guidelines

- ISO 14047: Environmental management - Life cycle assessment - Illustrative examples on how to apply ISO 14044 to impact assessment situations

- ISO 14071: Environmental management - Life cycle assessment - Critical review processes and reviewer competencies

This is only a piece of the global push for better informed environmental policy. The inclusion of quantified analysis tools in regulatory frameworks and legislation is a positive step forward to fully understanding the environmental impact of the choices that are made at the highest levels.

A cost-benefit analysis (CBA) is another technique that is commonly used to look at products, processes, or legislation to objectively quantify the costs involved and compares them with their benefits. The cost-benefit analysis will not only account for the direct economic costs, but for the costs to the whole process, product, or legislation. Similarly to the life cycle analysis, the cost benefit analysis required quantified data for items that have not traditionally been communicated with quantified data.

The Building Research Establishment (BRE) conducted a cost-benefit analysis to study the effect of sprinkler systems in warehouses. They assumed six building types ranging from small to large warehouses, with or without sprinklers. The analysis considered the "Whole Life Costs" of a building. This took into account such things as the buildings area, to the annual maintenance of the system to the frequency and impact of a fire. The impacts such as the size and impact of the smoke were taken into account as well as the injuries/casualties, and whether the building needed to be demolished (BRE Global, 2013).

The environmental impact of fire has been done using two metrics one metric is using tons of $\mathrm{CO}_{2}$ and the other is using ecopoints. Where ecopoints are normalized so that the annual environmental impact of an average person is 100 ecopoints. The data points that are used to make up that metric are as follows:

The cost-benefit analyses is useful for studying the environmental impact of fire as a basis for design including the fire protection systems because it presents the information as economic data. The study from BRE looking at whether to include sprinklers is one example, but the cost-benefit analysis could also be used to study any aspect of the fire system design. The boundaries of a cost- 
benefit study can vary, so it is advised that an official document is used to bound and define the analysis using something like ASTM E917.

Risk assessment is used across many industries, for many uses, because of its power for identifying the various hazards and the likelihoods of a hazardous even occurring. An environmental impact analysis benefits from a full risk assessment to properly understand the impacts. The use of risk assessment techniques will also allow translation to risk management and risk-informed decision making.

There are numerous methods for conducting a risk assessment exercise, which are in part dependent on the level of detail needed and the data that is available. There are three main levels of detail by which risk can be assessed, which are through purely qualitative methods, semi-quantitative methods, or purely quantitative methods. A qualitative risk assessment analysis will

\begin{tabular}{ll}
\hline - Acidification & - Photochemical Ozone Creation \\
- Eutrophication & - Fossil Fuel Depletion \\
- Waste Disposal & - Exotoxicity to land \\
- Nuclear Waste & - Exotoxicity to Freshwater \\
- Human Toxicity & - Stratospheric Ozone Depletion \\
- Mineral Resource Extraction & - Water Extraction \\
- Climate Change & \\
\hline
\end{tabular}

require the least level of detail and the least data, whereas a quantitative risk assessment analysis will require the highest level of detail and more data. The types of analysis that can be done range from a simple unstructured method to a quantitative risk assessment (QRA) or probabilistic risk analysis (PRA) (Ramachandran \& Charters, 2011). Other methods include (Morandini et al. 1991), (Ramachandran \& Charters, 2011):

The process of risk assessment can be conducted through a variety of methods depending on the problem being studied and the results that are desired. The process of assessing the risk of fire on the environment requires additional study because of the gaps in our knowledge as well as the specificity and complexity of the issues involved.

There were two major organizations that were working in this area and provided good guidance on future steps. The first is the Environmental Protection Agency (EPA). The EPA uses the framework shown in Fig. 7 to conduct their ecological risk assessments. The other organization that is influential for looking at the environmental impacts of fire is the United States Department of Agriculture (USDA). The USDA, in conjunction with its child organization the United States Forest Service (USFS), has done a significant amount of work to assess the impacts of wildland fire-fighting chemicals (Modovsky, 2007) and the impacts seen at the Wildland-Urban Interface (WUI) (USDA, 2013).

To perform a fully formed risk assessment a proper framework needs to be identified. Figure 8 represents a piece of the problem for assessing the environmental impacts of fire. First there is the source of the risk, which in this case will be the fire. The source itself is com-

\begin{tabular}{|c|c|}
\hline - HAZAN - Hazard Analysis & - Matrix Methods \\
\hline - Checklists & - GOFA - Goal Oriented Failure Analysis \\
\hline • Delphi & • HAZID - Hazard Identification \\
\hline $\begin{array}{l}\cdot \text { HAZOP - Hazard and } \\
\text { Operability Study }\end{array}$ & - Quantative Risk Assessment (QRA) \\
\hline $\begin{array}{l}\text { - Probabilistic Risk Assessment } \\
\text { (PRA) }\end{array}$ & - Consequence Analysis (CA) \\
\hline - Fault Tree Analysis (FTA) & - Event Tree Analysis (ETA) \\
\hline $\begin{array}{l}\text { - Cause-Consequence } \\
\text { Analysis }\end{array}$ & $\begin{array}{l}\text { - Failure Modes, Effects, and Criticality } \\
\text { Analysis (FMECA) }\end{array}$ \\
\hline
\end{tabular}

prised of several hazards of concern, ranging from chemical, physical, biological, or nutritional. These make up the hazards in the risk assessment process. The pathways, or the ways that the hazards gets from the source to the target are of critical importance. In the case of fire and many other events, the pathways for the impact is through the air, water, and the ground. For the hazard to reach the target it still needs a way to affect the organism or area through either ingestion or contact. Once the hazard reaches the target (receptor) the target must process the hazard, be affected by the toxicity, and then think about the final effects. There are some hazards that are able to be processed, but it is very dependent on the toxicity of the hazard. The toxicity is separated into how it affects the target. The toxicity is either acute, sub-chronic, chronic, or intermittent.

An example of this process is a source fire is being extinguished with water, where the hazard is the chemical runoff, the water then flows to a river by means of the surface water runoff. The targets of fish, crustaceans, and algae all either ingest or contact the chemical runoff. The chemicals are then absorbed and metabolized when the target processes the chemical. The toxicity of the exposed depends of the population, size and potency of the chemicals but ultimately it can cause birth defects or mortality in the species in the river.

Environmental Policy is typically broken down into the different pathways through which the environment is exposed to stressors (hazards). These include air quality, 


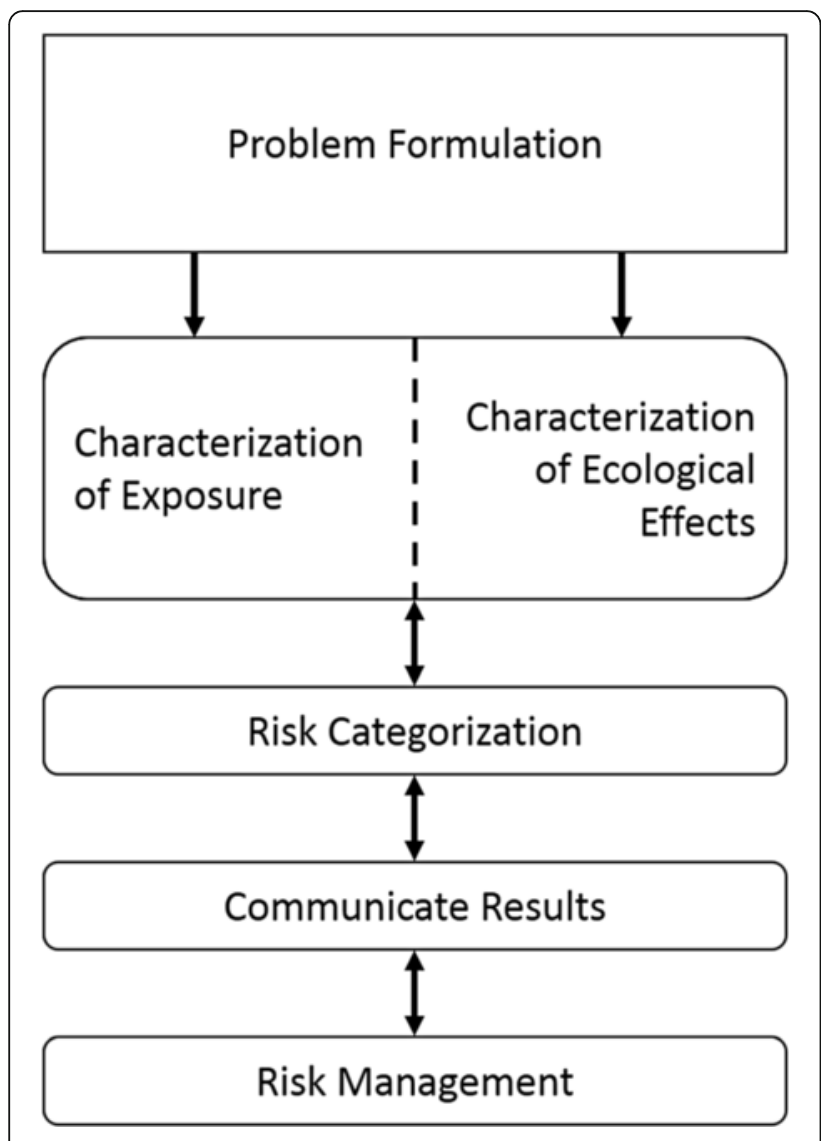

Fig. 7 EPA Risk Assessment Framework (EPA, 1998) (Additional file 1)

surface water quality, ground water health, soil health, solid waste management, and food safety.

Additionally there is legislation that focuses on the Environmental Impacts themselves, which typically requires an environmental impact statement (EIS) to prove that the environmental impact will be limited.

Historically environmental legislation is difficult to implement because it is not only a local issue, but also a regional issue as well as global issue. Global groups like the United Nations greatly assist in unifying the ideas and policies. The following includes a list of regulatory sources for environmental policy. This is included to provide an idea of what the different regions and countries have done to reduce environmental impact and because one possible outcome of this research is additional legislation it was decided to include examples from around the world.

\section{Global Groups}

O United Nations (UN)

The United Nations provides guidance on their version of an environmental impact assessment through their Economics and Trade Branch that is under the Environment program. (UN, n.d)
International Standards Organization (ISO)

- ISO 16732-1:2012 Fire safety engineering - Fire risk assessment - Part 1: General

- ISO/TR 16732-2:2012 Fire Safety Engineering Fire risk assessment - Part 2: Example of an office building

- ISO/TR 16732-3:2013 Fire safety engineering Fire risk assessment - Part 3: Example of an industrial property

2. Regional Groups

O Asia

The Asian Environmental Compliance and Enforcement Network (AECEN) is a collaborative effort across the countries of Cambodia, China, India, Indonesia, Japan, Korea, Laos, Malaysia, Maldives, Myanmar, Nepal, Pakistan, Philippines, Singapore, Sri Lanka, Thailand, and Vietnam. This regional group works to improve collaboration across the region. (AECEN, n.d.)

$\bigcirc$ European Union (EU)

The European Union is a collection of Nations on the European continent. Their legislation was first adopted 25 years ago in 1990 (European Comission, n.d.)

3. Individual Countries

Australia (Australian Government, n.d.)

$\bigcirc$ Canada (Canadian EAA, n.d.)

China (NPC, n.d.)

$\bigcirc$ Egypt (EEAA, n.d.)

$\bigcirc$ Hong Kong (EPD, n.d.)

$O$ India (EFCC, n.d.)

Ireland (EPA, n.d.)

Malaysia (Department of Environment, n.d.)

$O$ New Zealand (NZAIA, n.d.)

$\bigcirc$ Sri Lanka (CEA, n.d.)

$\bigcirc$ United States (US EPA, n.d.)

\section{Decision making}

Evaluating the environmental impact of fire would beneficial on the design period of a building, by including in a decision making process. The analysis tools mentioned above, offer a useful starting point to evaluate a product, process, or new legislation aimed at promoting or incorporating an environmental impact assessments. There are several steps that could be taken to improve access to useful tools, methodologies and frameworks pertaining to the environmental impact of fire. The tools for analyzing the environmental impact have the potential to help in decision making, by displaying an analysis of different factors for stakeholders. The CRC handbook compiles several decision making tools with different advantages for decision making, including matrices, lifecycle analysis, looking at effects on the ecology, looking at effect on the future, and risk measurement. 


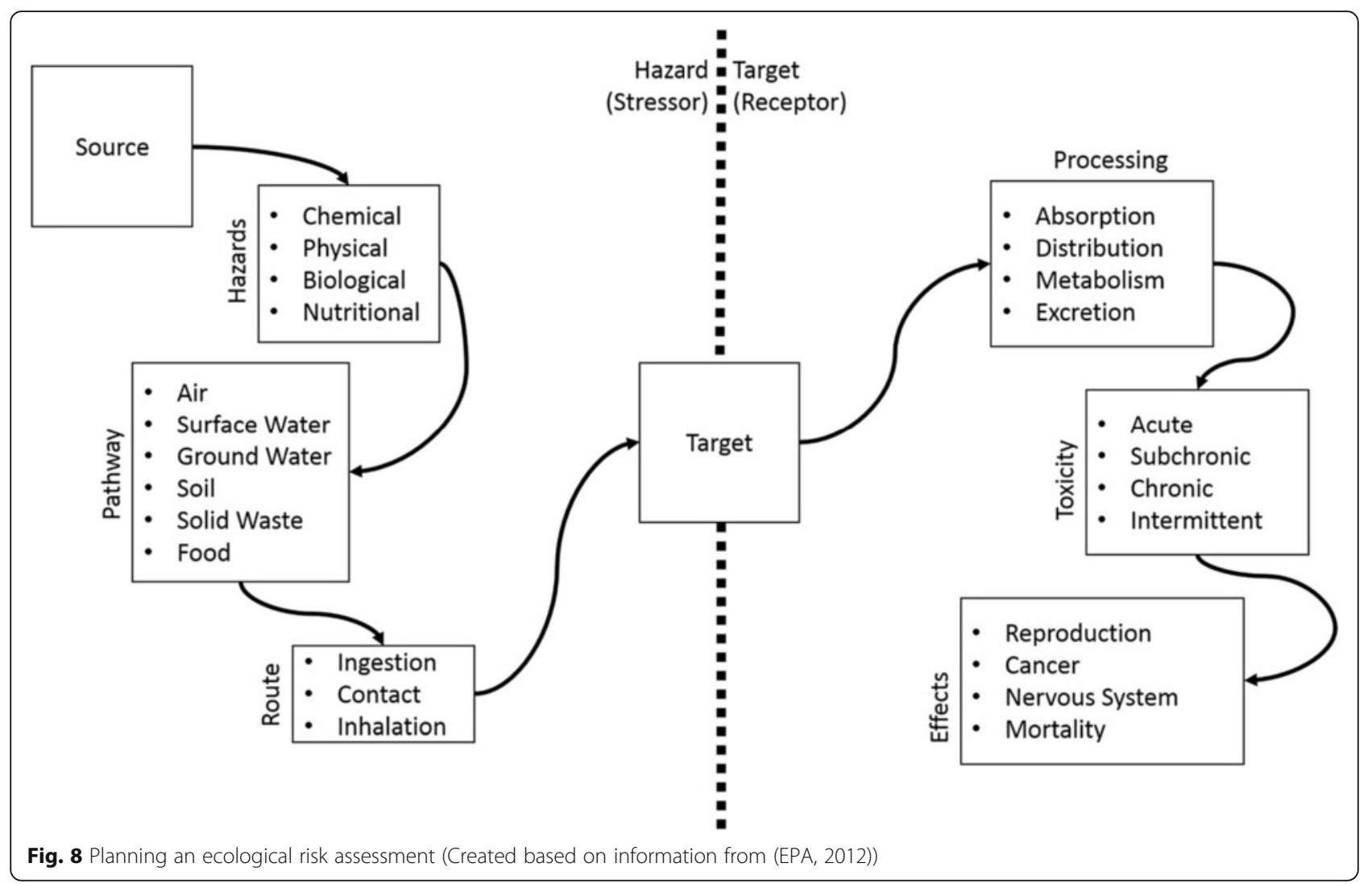

Table 5 is an example of a matrix technique that can be used to rate the criteria in terms of the impact. This is a powerful tool to break down environmental effects and their sources. For example, a small scale residential fire event can be analyzed as below:

The impacts range from adverse to not applicable and can be quickly estimated based upon a qualitative assessment. The initial assessment considers the atmosphere which corresponds to the impact severity classification based on the different phases of the fire. The fire plume effluents are the buoyant products of combustion that are carried upwards and dispersed through the air. The fire department intervention describes the impacts resulting from fire department intervention. The long term effects column describes what impacts the environment will be affected by in the months or year after the fire. The resultant quality of the environment is different than the long term effects in that it describes the result of the aftermath of the fire, and gives an idea as to the severity of the effects.

The application of a life cycle analysis (LCA) for observing the environmental impacts of fire is made easier by the prevalent use of this tool in other fields. Tools already exist, utilizing a LCA, for designers to understand the impact of choosing one material or building method over another.

One example of a LCA process, that can be used for decision making, is from the United States Department of Defense (ODUSD(I\&E), 2013). This example is especially pertinent, because it performs an adaptation to the typical LCA process to create the streamlined life cycle

Table 5 Example of interaction matrix between environmental factors and effects of the fire

\begin{tabular}{llllll}
\hline Environmental & Existing & \multicolumn{3}{c}{ Fire Phase } \\
\cline { 3 - 6 } Factor/ Resource & Quality & Fire Plume Effluents & Fire Department Intervention & Long Term Effects & Resultant Quality \\
\hline Atmosphere & NA & $A$ & $A$ & 0 & $A$ \\
Ground Water & NA & $M$ & $M$ & $A$ & $a$ \\
Plants and Animals & NA & $O$ & $a$ & 0 & $a$ \\
Subsurface & NA & $O$ & 0 & 0 & 0 \\
Acoustics & NA & $O$ & 0 & 0 & 0
\end{tabular}

$A$ adverse impact, $M$ mitigation measure planned, a small adverse impact, $O$ No anticipated impact, $N A$ Environmental Factor not Applicable, $S A$ Significant Adverse Impact, $b$ small beneficial impact, $B$ beneficial impact, $S B$ significant beneficial impact 
assessment (SLCA). The SLCA is useful as a decision tool to compare the relative magnitude of impacts between two or more choices. It simplifies the process by selecting inputs that were found to be the most restrictive factors in a typically LCA. The factors used include emissions and qualitative measurements of water and land impacts.

By linking generalized emissions data the result is easier to obtain a comparison between two different data sources. The differences between the inputs for the LCA and the SLCA are applied at the point where the system inputs are translated to the system processes and then to outputs. By simplifying the processes in the system the input effects can summarized and more efficiently translated into the system outputs. This simplifies the most restrictive part of an LCA; the amount and complexity of the inputs that are required. However in this example the number of inputs is simplified by generalizing the emissions factors, and by using scoring factors to characterize the impacts on the water and land. Using a system of generalized data allows for easier data input with little loss in quality of the results (ODUSD(I\&E), 2013).

A spider graph is a different tool than the matrix approach, with the advantage is that the ultimate outcome is a visual, where the scenario with the largest area corresponds to the most severe environmental impact. A visual of the differences between two options can reveal how the items in question vary and which choices lead to the least environmental impact. Additionally, because the impacts are normalized the value of the environmental impact for each criterion offers a clear comparison of each alternative.

Risk characterization is part of a process that begins with the formation of a problem and ends with a decision (Understanding Risk, 1996). The multidimensionality of risk and the many ways it can be viewed help explain why risk characterizations sometimes lack authority for some of the interested and affected parties when making a decision, even when the characterizations are supported by high-quality analysis. Problem formulation has practical implications for other steps in the risk decision process in the way that it shapes choices about which options to consider and which possible adverse outcomes to analyze. A risk characterization must consider the range of plausible decision options to meet the needs of participants in a decision, to avoid being seen as biased and inadequate. Organizations responsible for risk characterizations should make efforts to identify the range of decision options that experts and the spectrum of interested and affected parties consider viable. This process demands familiarity with the context of decision, knowledge about scientific and technical aspects of the possible risks, and sometimes creativity and imagination.
One important outcome of decision making tools is to assess the harm to nonhuman organisms and ecosystems (Understanding Risk, 1996). An analysis can be challenging as it is difficult to determine the effects on individual animals or plants, local populations of a certain species, an ecosystems, or on the survival of endangered species. Ecological risk analysis requires an understanding of how the affected ecosystem functions. These effects are difficult to measure and are still being studied to understand the outcome. Qualitative assessments of ecological risks can provide useful insights for environmental decision making. There is a need to develop appropriate tools for assessing the value of ecological systems, including both economic and noneconomic values.

Decisions which have an effect on future generations require a different kind of consideration from immediate concerns (Understanding Risk, 1996). The largest wildfires in history have been over the last decade and are fueled by drought, disease and hotter temperatures as well as forest management techniques. This problem is made up of both environmental factors as well as management decisions and changes in population locations that in combination are resulting in large challenges for the current generation. Large forest fires leave damage on the environment as it burns down trees, produces effluents, and kills lives of plants, insects and animals, however opposed to small fires is the temperatures at which larger fires burn. The hotter temperatures cause much more of the soil to be burned causing sterility in the top layer and limits the ability for new growth. The results might not lead to an immediate negative influence, but the releases of toxic materials and physical change of the land could cause harm in the future. A large loss of species could lead to change in an ecosystem, which could lead to a potential damage on the environment. It is difficult to assess the risks to future generation without considering possible social changes as well as the operation of physical and biological processes over the long term.

The trend for larger fires in recent years has caused forest managers to evaluate how they protect their forests. One major hazard is the amount of fuel loading that has accumulated because of the suppression of health fires. Now and in the future it is expected that more thinning and prescribed burns will be conducted to get the forest and its fuel load at a healthy level. Additionally there have been a number of studies of the wildland-urban interface (WUI), which has resulted in greater compliance with WUI best-practices in wildland affected areas, like Oregon.

Choosing a risk measure for an event, or piece of regulation is complex and subjective (Understanding Risk, 1996). It differs depending on the focus and the 
observed outcomes. For example, the list below shows different ways that risks of a fire can be measured:

- Death per million people in the population

- Death per million people within $\mathrm{x}$ miles of the source

- Death per unit of concentration

- Death per facility

- Deaths per ton of toxic substance released

- Deaths per million dollars of product produced

The selection of the metric through which impacts are measure can make a significant difference in a comparative analysis. It is imperative to clarify what information is presented and from what point of view. An environmentalist might be more interested in the amount of toxic substances released, as opposed to a policymaker who might be interested in the number of deaths per facility. One metric has greater relevance than the other depending on the observer of the problem.

\section{Gaps}

This research has identified that a significant amount of information is available regarding the environment and the fire effects. However, the information is not complete, nor are the means to utilize that information in decision making. The following gaps have been identified, where additional knowledge and information could be researched in more depth and made available for decision makers.

\section{Reporting/Study post fire event}

From the beginning of the report several high profile fires with adverse environmental effects were described. For those fires, some information was able to be tracked down, but it was surprising how difficult it was. For most other fires, where concern for the environment was not considered there is little information. A reporting mechanism for fire departments to provide any feedback regarding the risk management of the fire during the event should be explored.

\section{Process for EIA during construction}

It is becoming common place for buildings to be constructed with some level of certification as to their sustainability, namely LEED in the United States. The building codes are catching up to this level of energy efficiency. It is recommended that an environmental impact assessment (EIA), which includes a fire event, be considered.

Risk assessment tools for fire departments

There are some fire events which had beneficial environmental risk assessment conducted by incident command, however there were also some fire events where better defined risk management techniques would have provided better guidance for incident commanders. New tools and methods should be explored that provide fire departments with a clearer direction about which intervention technique(s) would be the most beneficial.

\section{Exploring the impact of building contents}

The contents of a building can change from year to year or even hour to hour depending on the occupancy. The contents of a building can make a difference when choosing a design fire for a space and it is seemingly similar for an environmental impact study. For example a large warehouse filled with bricks would be very different than a warehouse filled with fertilizer, herbicide, and other pesticides both in terms of the fire and that the environmental impacts would result. It is recommended that some sensitivity studies be conducted to determine the effect of contents beyond the studies from FM Global and BRE.

\section{Exploring the impact of fire retardants}

As building contents change to be more susceptible to fire, new fire retardants are being created to challenge the fire ignition and initial growth. It is recommended that a database of fire retardants and the products of combustion, when they are burned, is created to more fully understand their hazard and toxicity.

\section{Detailed fire information for global fire problem}

NFPA provides good records of the fire problem in the United States, as do many other countries, but it is difficult to find consistent information regarding fires for the entire world. With the advance of sustainable design and rigid guidelines being developed there should be additional detailed records kept about the fire. The record keeping of fire events in other countries is most likely a political issue as well as a logistical issue, regardless options for expanding fire and environmental impact events should be explored.

\section{Conclusions and future work}

The environmental impact of fire is a topic that has gained interested in recent years in association with a more holistic review of a building foot print This research presents a broad look at the general areas in which fire has an impact, what the definition of an impact is, how the impacts can be calculated and what can be done with that information.

This paper offers a review of the context of the environmental impact of fire in terms of how historical events impacted the current thinking on the subject. The Basel fire in Switzerland caused severe and long-lasting environmental damage as a result of water runoff. The result 
of this event was to have a larger emphasis on the containment of water runoff as well as observation of how fire and firefighting activities can impact the environment.

Fire has the potential to have an impact over both time and space, meaning that fires can be massive as in the case of wild fires and they can also cause longlasting damage stretching into decades of recovery time. Fire effluents can be fairly benign or extremely hazardous depending on what is burning. The target of an impact is also important when determining the impact of a fire and in this research the focus was on the natural environment and not human beings. A significant difference emerges between the impacts of a fire in the built environment and a wildfire as a result of the scale, duration and fuel loading of these different events.

Different methodologies for analyzing the impacts of fires range from a complete life cycle analysis, to a costbenefit analysis, to a risk assessment. A life cycle analysis is beneficial for understanding the impacts of specific product, especially where a project can be fully broken down into its component parts. An LCA is a data intensive process, which makes it well suited to understand the impacts of fire at the component level. The costbenefit analysis and risk assessment tools are well suited for understanding bigger picture impacts, such as changes to legislation or changes in tactics for lessening the impact of fire.

The research revealed a number of gaps and opportunities for future research, which should be considered. A major issue for understanding the impacts of fire is the collection and dissemination of data. The growth of LEED and other rating systems elsewhere provides a system for incorporating fire and other extreme events, but this has not yet been achieved. Additional research should be done on tactics and tools to be used by the fire department to lessen the environmental impacts when fighting a fire. Building contents are generally considered for their properties, however further consideration towards their impacts on the environment need to be considered. Fire retardants are a contentious issue for whether the benefit of minimizing flame spread outweighs the health impacts of the chemicals used.

This effort identified, summarized and compiled a large database of resources which help to define issues associated with characterizing the environmental impacts of fire. The outcomes of this effort can provide solid foundation for additional research in this area. The following outlines future research which could be of benefit in this area. Three major areas for future research are suggested, each aimed at providing environmental impact assessment tools for different stakeholder groups:

1. Decision tool for first responders

i) Quantified information about hazards ii) Quantified information about contents

iii) Quantified information about fire extinguishing materials

iv) Risk management framework for quick/easy analysis

v) Methodologies to report environmental impacts of fires

vi) Survey to determine, whether and to what extent first responders consider environmental impacts of fire

2. Decision tools for designers

i) Quantified information regarding hazards

ii) Tool describing differences of the environmental effects of one product undergoing combustion versus another product

iii) Survey to determine, whether and to what extent designers consider environmental impacts of fire

iv) Development of a decision tool incorporating quantified analysis techniques $\{\mathrm{LCA}, \mathrm{CBA}, \mathrm{RA}\}$ to compare the levels of fire protection at the design stage.

3. Decision tool for policy makers

i) Information regarding aggregate fire problem

ii) Methods of gathering necessary data from the international community

iii) Comparative study of existing global regulatory frameworks

iv) Study to identify paths to incorporating fire in environmental policy

v) Survey to determine, whether and to what extent policy makers consider environmental impacts of fire

vi) Development of a decision tool incorporating quantified analysis techniques $\{\mathrm{LCA}, \mathrm{CBA}, \mathrm{RA}\}$ to compare the levels of fire protection at the building code/policy level.

Prioritization of these efforts will depend on the goals and objectives of the responsible stakeholder groups. If the goal is to improve the environmental impact from first responders and the fire service then number one (1) should be undertaken to understand more fully the environmental impacts that the fire service contributes when attacking a fire and what possible changes they can make to reduce their environmental impact. Similarly fire protection designers can make a number of choices that affect the environmental impact of a building when considering if a fire does occur. There are numerous tools that exist to calculate the environmental footprint of a building and similar techniques could be used to account for the effects of fire. Number two (2) would involve exploring ways to incorporate the comparable sustainability between different types of fire protection measures. This could help answer questions as to what extent should sprinklers be 
implemented versus structural fire protection. The decision tool for policy makers described in number three (3) could be developed to understand the fire problem from a holistic viewpoint including the use of fire protection (preventive) and fire intervention (attack). To accomplish this an agreed way to calculate the aggregate effects of the fire would need to be established. A large concern with doing this currently is the lack of equivalent data from country to country. Another concern that needs to be addressed is which impacts are considered important and how to rank impacts that effect different parts of the environment, for different periods of time. If these can be resolved it is recommended that we determine an aggregate data set for comparison to other sources of environmental impacts as well as to get an accurate picture of the problem. Then ways to better incorporate prevention and intervention techniques could be implemented from a policy point of view. The regulation that is being written to save homes and buildings from wildfires by implementing WUI policies in one example of possible outcomes of this level of study like was included in updates to NFPA 1141 and NFPA 1144.

\section{Additional file}

Additional file 1: Appendix A: Review of Selected References. (DOCX 75 kb)

\section{Competing interests}

The authors declare that they have no competing interests.

\section{Authors' contributions}

BM, DM, MT contributed equally to this paper. All authors read and approved the final manuscript.

\section{Acknowledgement}

The authors give their thanks to the Fire Protection Research Foundation (FPRF) and the National Fire Protection Association (NFPA) for their support. The FPRF generously provided funding and guidance for this research project, which was awarded to Worcester Polytechnic Institute (WPI) in Worcester, MA. The authors appreciate the efforts of the project technical panel who consisted of experts from different parts of the industry as follows

Dave Butry, NIST

Janice Coen, National Center for Atmospheric Research

Ken Dungan, Risk Technologies LLC

Pravin Gandhi, UL

Chris Gallo, EPA

Kenan Ozekin, Water Research Foundation

Debbie Smith, BRE

Chris Wieczorek, FM Global

Ray Bizal, NFPA

Meghan Housewright, NFPA

Tracy Vecchiarelli, NFPA

\section{Author details}

${ }^{1}$ Arup, San Francisco, CA, USA. ${ }^{2}$ Worcester Polytechnic Institute, Worcester, USA.

Received: 31 March 2016 Accepted: 4 August 2016

Published online: 08 September 2016

\section{References}

Ahrens M (2013) Home Structure Fires. National Fire Protection Association, Quincy, Retrieved from http://www.nfpa.org/ /media/Files/Research/ NFPA\%20reports/Occupancies/oshomes.pdf

Andersson P, Simonson M, Rosell L, Blomqvist P, Stripple H (2003) Fire-LCA Model: Furniture Study., SP Fire Technology, Retrieved from http://www.sp. se/en/index/services/firelca/sidor/default.aspx

Andersson P, Simonson M, Tullin C, Stripple H, Sundqvist J, Paloposki T (2004) Fire-LCA Guidelines., SP Flre Technology, Retrieved from http://www.sp.se/ en/index/services/firelca/sidor/default.aspx

ASTM E917 (2013) ASTM E 917: Standard Practice for Measuring Life-Cycle Costs of Buildings and Building Systems., Retrieved from ASTM.org: http://www. astm.org/Standards/E917.htm

Bhargava M, Sirabian R (2011) SiteWiseTM Version 3 User Guide, Navy, NAVFAC EXWC. NAVFAC Engineering and Expeditionary Warfare Center, Hueneme, Retrieved from http://www.navfac.navy.mil/content/dam/navfac/Specialty\% 20Centers/Engineering\%20and\%20Expeditionary\%20Warfare\%20Center/ Environmental/Restoration/er_pdfs/s/navfacexwc-ev-ug-1302-sitewise320130807.pdf

Blomqvist P (2005) Emissions from Fires, Doctoral Thesis. Lund University, Department of Fire Safety Engineering, Lund, Retrieved from http://lup.lub.lu. se/luur/download?func=downloadFile\&recordOld $=545459$ \&fileOld $=545460$

Bowick M, O'Connor J, Meil J (2014) Athena Guide to Whole-building LCA in Green Building Programs. Athena Sustainable Materials Institute, Ottawa, Retrieved from http://www.athenasmi.org/wp-content/uploads/2014/03/ Athena_Guide_to_Whole-Building_LCA_in_Green_Building_Programs_ March-2014.pdf

BRANZ (2012). Building Sustainability and Fire-Safety Design Interactions: Scoping Study. Retrieved from http://www.branz.co.nz/cms_show_download. php?id=716733515027fe4626188881f674635d51e3cfb0.

BRE Global (2013) An Environmental Impact and Cost Benefit Analysis for Fire Sprinklers in Warehouse Buildings. The Business Sprinkler Alliance, London, Retrieved from http://www.business-sprinkler-alliance.org/wp-content/ uploads/2014/01/BRE-Report.pdf

Brnich M Jr, Kowalski-Trakofker K (2010) Underground Coal Mine Disasters 19002010: Events, Responses, and a Look to the Future., Retrieved from http:// www.cdc.gov/niosh/mining/UserFiles/works/pdfs/ucmdn.pdf

Bussum L (2013) National Fire Weather Report. NWS Fire Weather Operations Coordinator, Boise, Retrieved from National Weather Service: http://www.srh. noaa.gov/ridge2/fire/docs/National_Report_2013.pdf

CEGIS (2014) Center of Excellence for Geospatial Information Science (CEGIS). Retrieved from USGS - CEGIS, http://cegis.usgs.gov/

Clinton N, Gong P, Scott K (2006) Quantification of Pollutants emitted from very Large Wildland Fires in Southern California, USA, Atmospheric Environment., pp 3686-3695

CRC (1999) Environmental Impact Assessment. In: Environmental Engineer's Handbook. CRC Press LLC, Boca Raton

DOE (2011) Buildings Energy Data Book. United States Department of Energy, Silver Spring, Retrieved from http://buildingsdatabook.eren.doe.gov/ docs\%5CDataBooks\%5C2011_BEDB.pdf

EPA (1991) Kuwait Oil Fires: Interagency Interim Report. Environmental Protection Agency, Washington, Retrieved from http://nepis.epa.gov/Exe/ZyPURL. cgi? Dockey $=90050000 . t x t$

EPA (1998) Guidelines for Ecological Risk Assessment. Environmental Protection Agency. Retrieved from https:/www.epa.gov/sites/production/files/2014-11/ documents/eco_risk_assessment1998.pdf. Accessed 17 Aug 2016

EPA (2008) Polycyclic Aromatic Hydrocarbons (PAHs)., Retrieved from Environmental Protection Agency, https://www.epa.gov/sites/production/ files/2014-03/documents/pahs_factsheet_cdc_2013.pdf

EPA (2012) Planning an Ecological Risk Assessment., Retrieved from EPA Risk Assessment, https://www.epa.gov/risk/guidelines-ecological-risk-assessment

Evans D, Madrzykowski D, Haynes G (1994) Flame Heights and Heat Release Rates of 1991 Kuwait Oil Field Fires, NIST. Fire Safety Science, Ottawa, Retrieved from http://fire.nist.gov/bfrlpubs/fire94/PDF/f94064.pdf

Evarts B (2012) Fires in U.S. Industrial and Manufacturing Facilities. National Fire Protection Association, Quincy, Retrieved from http://www.nfpa.org/research/ reports-and-statistics/fires-by-property-type/industrial-and-manufacturingfacilities/fires-in-us-industrial-and-manufacturing-facilities

FM Global (2010) Environmental Impact of Automatic Fire Sprinklers. FM Global Research Division, Norwood, Retrieved from http://www.iccsafe.org/gr/ 
Documents/AdoptionToolkit/FM-GlobalEnvironmenmtallmpactAutomaticFireSprinklers.pdf

Hall J (2013) High-Rise Building Fires. National Fire Protection Association, Quincy, Retrieved from http://www.nfpa.org/ /media/Files/Research/ NFPA\%20reports/Occupancies/oshighrise.pdf

Hamzi R, Londiche H, Bourmada N (2008) Fire-LCA Model for Environmental Decision-Making. Chem Eng Res Design, 1161-1166. doi:10.1016/j.cherd. 2008.05.004. Accessed 17 Aug 2016

Health and Safety Commission (c) (2006) Buncefield Major Incident Investigation., Retrieved from http://www.endsreport.com/docs/20060713d.pdf

Health and Safety Executive (1993) The fire at Allied Colloids Limited. A report of the HSE's investigation into the fire at Allied Colloids Ltd, Low Moor, Bradford on 21 July 1992., Retrieved from http://www.icheme.org/ communities/special-interest-groups/safety\%20and\%20loss\%20prevention/ resources/ /media/D3C58AAE7B7D4BF392E3885D728AAC0E.pdf

Health and Safety Executive(b) (1995) BASF, Wilton, Teeside. 9th October 1995., Retrieved from Health and Safety Executive Case studies: http://www.hse. gov.uk/comah/sragtech/casebasf95.htm

Holemann H (1994) Environmental problems caused by fires and fire-fighting agents, IAFSS., Retrieved from http://www.iafss.org/publications/fss/4/61/view

ICC (2012a). International Building Code, 2012. Retrieved from http:// premiumaccess.iccsafe.org/document/toc/353/

ICC (2012b) International Fire Code, 2012. Retrieved from http://premiumaccess. iccsafe.org/document/toc/332/

ISO (2011) ISO/CD 26367-2 Guidelines for assessing the adverse environmental impact of fire effluents., Retrieved from http://www.iso.org/iso/home/store/ catalogue_tc/catalogue_detail.htm?csnumber $=50635$

ISO (2014) ISO/TC 207/SC 5 - Life cycle assessment., (I. O. Standardization, Producer) Retrieved from ISO: http://www.iso.org/iso/home/store/catalogue tc/catalogue_tc_browse.htm?commid=54854

Karter MJ (2014) NFPA., Retrieved from Fire Loss in the United States During 2013: http://www.nfpa.org/ /media/Files/Research/NFPA\%20reports/ Overall\%20Fire\%20Statistics/osfireloss.pdf

Lippiatt B, Greig A, Lavappa P (2010) BEES., Retrieved from NIST.gov: http://www. nist.gov/el/economics/BEESSoftware.cfm

Marlair G, Simonson M, Gann R (2004) Environmental Concerns of Fire: Facts Figures, Questions and New Challenges for the Future, NIST., Retrieved from http://fire.nist.gov/bfrlpubs/fire04/PDF/f04038.pdf

McNamee M (2014) Guest Editorial: Fire and the Environment. Fire Tech, 1-2. doi:10.1007/s10694-014-0444-z

Modovsky C (2007) Ecological Risk Assessment: Wildland Fire-Fighting Chemicals, Labat Environmental. United States Forest Service, Missoula, Retrieved from http://www.ff.fed.us/rm/fire/wfcs/documents/era_pub.pdf

Morandini S, Maher S, Schene R (1991) Using Fault Tree Analysis to Identify CostEffective Design Improvements in Offshore Platform Safety Shutdown Systems. In: Cox R, Walter M (eds) Offshore Safety and Reliability. Elsevier Science Publishing, New York, pp 201-211

National Interagency Fire Center (2014) Federal Firefighting Costs (Suppression Only)., Retrieved from National Interagency Fire Center, https://www.nifc.gov/ firelnfo/firelnfo_documents/SuppCosts.pdf

Nelson G (2000) Fire and Pesticides, A Review and Analysis of Recent Work. Fire Tech, 163-183. Retrieved from http://link.springer.com/article/10.1023/ A\%3A1015462710856. Accessed 17 Aug 2016

New Zealand Fire Service (2001) The Ecotoxic Effects of Fire-Water Runoff: Part I: Literature Review., Retrieved from http://www.fire.org.nz/Research/PublishedReports/Documents/2a6e4acb13e45a94afef2c9550adbd24.pdf

NFPA (2012) NFPA 1: Fire Code Handbook. NFPA, Quincy

NFPA (2013a) Largest Loss Wildland Fires., Retrieved from NFPA Reports and Statistics, http://www.nfpa.org/research/reports-and-statistics/outdoor-fires/ largest-loss-wildland-fires

NFPA (2013b) Structure Fires by Occupancy 2007-2011- Annual Averages. Retrieved from NFPA, http://www.nfpa.org/ /media/files/research/nfpareports/occupancies/osstructurefiresoccupancy.pdf?la=en

NIFC (2014) National Interagency Fire Center Year-to-date statistics., Retrieved from National Interagency Fire Center, http://www.nifc.gov/firelnfo/nfn.htm

Nolter M, Vice D (2004) Looking back at the Centralia coal fire: a synopsis of its present status. Int J Coal Geol, 99-106. doi:10.1016/j.coal.2003.12.008. Accessed 17 Aug 2016

ODUSD(I\&E) (2013) Streamlined Life Cycle Assessment Process for Evaluating Sustainability in DoD Acquisitions. DOD, Office of the Deputy Under Secretary of Defense (Installations \& Environment). Department of Defense. Retrieved from http://www.denix.osd.mil/esohacq/home/. Accessed 17 Aug 2016

Pennsylvania Department of Environmental Protection (2013) The Centralia Mine Fire Frequently Asked Questions/Answers., Retrieved from PDEP: http://files. dep.state.pa.us/Mining/Abandoned\%20Mine\%20Reclamation/ AbandonedMinePortalFiles/Centralia/CentraliaFrequentlyAskedQuestions. pdf\#nameddest $=B$

Ramachandran G, Charters D (2011) Quantitative Risk Assessment in Fire Safety. Spon Press, New York

Salisbury H (1988) The Breath of the Black Dragon in Russia and China., Retrieved from New York Times, http://www.nytimes.com/1988/10/01/opinion/thebreath-of-the-black-dragon-in-russia-and-china.html

Simonson M, Andersson P, Blomqvist P (2005) Environmental Assessment of Fires in Products Using the Fire-LCA Model, Fire safety science-Proceedings of the Eighth International Symposium. International Association for Safety Science, Beijing, pp 1071-1082, Retrieved from http://www.iafss.org/publications/fss/ 8/1071/view. Accessed 17 Aug 2016

Simonson M, Andersson P, Rosell L, Emanuelsson V, Stripple H (2001) Fire-LCA Model: Cables Case Study. SP Swedish National Testing and Research Institute. SP Fire Technology. Retrieved from http://www.sp.se/en/index/ services/firelca/sidor/default.aspx

Simonson M, Blomqvist P, Boldizar A, Moller K, Rosell L, Tullin C, Sundqvist J (2000) Fire-LCA Model: TV Case Study. SP Technical Research Institute of Sweden. Retrieved from http://www.sp.se/en/publications/Sidor/ Publikationer.aspx?Publld=537. Accessed 17 Aug 2016

Turekova I, Balog K (2010) The Environmental Impacts of Fire-Fighting Foams. Faculty Mat Sci Technol Trnava, 111-120. Retrieved from https://www.mtf. stuba.sk/docs/doc/casopis_Vedecke_prace/29/12_turekova.pdf. Accessed 17 Aug 2016

USDA (2002) Wildland Fire in Ecosystems: Effects of Fire on Air. United States Deparment of Agriculture, Rocky Mountain Research Station, Retrieved from http://www.fs.fed.us/rm/pubs/rmrs_gtr042_5.pdf

USDA (2005) Wildland Fire in Ecosystems: Effects of Fire on Soil and Water. United States Department of Agriculture, Rocky Mountain Research Station

USDA (2013) Wildfire, Wildlands, and People: Understanding and Preparing for Wildfire in the Wildland-Urban Interface. United States Department of Agriculture, Washington DC, Retrieved from http://www.fs.fed.us/openspace/ fote/wildfire-report.html

USFA (1987) Sherwin-Williams Paint Warehouse Fire, United States Fire Administration., Retrieved from http://www.usfa.fema.gov/downloads/pdf/ publications/tr-009.pdf

USFS (2013) Forest Vegetation Simulator (FVS)., Retrieved from United States Forest Service, http://www.fs.fed.us/fmsc/fvs/

USFS (2015) Fire Detection GIS Data., Retrieved from USFS - Remote Sensing Applications Center, http://activefiremaps.fs.fed.us/gisdata.php

Wildland Fire Assessment System (2010) NDFD Fire Danger Point Forecast Tool, Retrieved from USFS-WFAS: Wildland Fire Assessment System: http://www. wfas.net/

\section{Submit your manuscript to a SpringerOpen ${ }^{\mathcal{O}}$ journal and benefit from:}

- Convenient online submission

- Rigorous peer review

- Immediate publication on acceptance

- Open access: articles freely available online

- High visibility within the field

- Retaining the copyright to your article

Submit your next manuscript at springeropen.com 